\title{
Article
}

\section{Interactome of Arabidopsis Thaliana}

\author{
Merve Yilmaz, Merle Paulic and Thorsten Seidel * $\mathbb{C}$
}

check for

updates

Citation: Yilmaz, M.; Paulic, M.;

Seidel, T. Interactome of Arabidopsis

Thaliana. Plants 2022, 11, 350.

https://doi.org/10.3390/

plants 11030350

Academic Editor: Monika Doblin

Received: 4 January 2022

Accepted: 25 January 2022

Published: 27 January 2022

Publisher's Note: MDPI stays neutral with regard to jurisdictional claims in published maps and institutional affiliations.

Copyright: (C) 2022 by the authors. Licensee MDPI, Basel, Switzerland. This article is an open access article distributed under the terms and conditions of the Creative Commons Attribution (CC BY) license (https:// creativecommons.org/licenses/by/ $4.0 /)$.

\begin{abstract}
Dynamic Cell Imaging, Biochemistry and Physiology of Plants, Bielefeld University, 33501 Bielefeld, Germany; merve.yilmaz@uni-bielefeld.de (M.Y.); merle.paulic@uni-bielefeld.de (M.P.)

* Correspondence: tseidel@uni-bielefeld.de
\end{abstract}

\begin{abstract}
More than 95,000 protein-protein interactions of Arabidopsis thaliana have been published and deposited in databases. This dataset was supplemented by approximately 900 additional interactions, which were identified in the literature from the years 2002-2021. These protein-protein interactions were used as the basis for a Cytoscape network and were supplemented with data on subcellular localization, gene ontologies, biochemical properties and co-expression. The resulting network has been exemplarily applied in unraveling the PPI-network of the plant vacuolar proton-translocating ATPase (V-ATPase), which was selected due to its central importance for the plant cell. In particular, it is involved in cellular $\mathrm{pH}$ homeostasis, providing proton motive force necessary for transport processes, trafficking of proteins and, thereby, cell wall synthesis. The data points to regulation taking place on multiple levels: (a) a phosphorylation-dependent regulation by 14-3-3 proteins and by kinases such as WNK8 and NDPK1a, (b) an energy-dependent regulation via HXK1 and the glucose receptor RGS1 and (c) a $\mathrm{Ca}^{2+}$-dependent regulation by SOS2 and IDQ6. The known importance of V-ATPase for cell wall synthesis is supported by its interactions with several proteins involved in cell wall synthesis. The resulting network was further analyzed for (experimental) biases and was found to be enriched in nuclear, cytosolic and plasma membrane proteins but depleted in extracellular and mitochondrial proteins, in comparison to the entity of protein-coding genes. Among the processes and functions, proteins involved in transcription were highly abundant in the network. Subnetworks were extracted for organelles, processes and protein families. The degree of representation of organelles and processes reveals limitations and advantages in the current knowledge of protein-protein interactions, which have been mainly caused by a high number of database entries being contributed by only a few publications with highly specific motivations and methodologies that favor, for instance, interactions in the cytosol and the nucleus.
\end{abstract}

Keywords: protein-protein interaction; Arabidopsis thaliana; interactome; Cytoscape

\section{Introduction}

Most proteins do not act alone but interact with others to fulfill a number of processes and functions within a cell [1]. For this reason, they often form protein complexes and molecular machines to facilitate and enable their proper function for the cell [1-3]. Proteinprotein interactions (PPI) are understood as physical contact, and molecular attaching between proteins and are a prerequisite for protein functioning in living cells [4]. Therefore, a better understanding of proteins and their respective function is facilitated by identifying protein-protein interactions. Analyzing and characterizing PPI contributes to an understanding of proteins' activity and response to biochemical, signaling and functional processes [1].

PPIs are essential or responsible for a broad spectrum of processes and functions, such as cell-cell interactions, the transformation and transportation of information through the cell and different transportation processes of molecules within a cell, such as the transport of ions, electrons and protons [5]. For instance, an impressive interaction of multiple proteins cooperates in mitochondria: electrons are transported to generate a proton motif 
force at the respiratory chain, which is used for ATP generation and includes the interaction of four major complexes [6,7]. Looking at the regulation of protein functions, the binding of calcium-binding EF-hand proteins, 14-3-3 proteins and thioredoxins acts as a cellular regulator [8-10].

Although there are a variety of methods to identify PPI, classical techniques comprise yeast-2-hybrid and mass spectrometry (MS) [11-13]; indeed, it is the development of these two methods that contributed the most to progress in identifying protein-protein interactions [11]. Whereas the classical yeast-2-hybrid assay depends on nuclear import of the interaction partners to enable transcriptional activation of the reporter, the matingbased split-Ubiquitin system (mbSUS) allows testing of interactions between membrane proteins, since a transcription factor is released by Ubiquitin-dependent proteases following bimolecular complementation of Ubiquitin [14,15]. However, one has to keep in mind that both approaches rely on a heterologous expression system, with its typical advantages and disadvantages regarding, for instance, the localization and developmental regulation of protein expression. Isolating complexes out of plant tissues or cells by co-immunoprecipitation or tandem affinity purification (TAP) ensures that the complexes have been exposed to their native environment while isolated [16,17], with the advantage of fewer false positives due to the tandem-affinity purification, despite the requirement for tagged bait proteins in the case of TAP [17]. In vivo assays such as Förster resonance energy transfer (FRET) between fluorescent proteins, or the bimolecular fluorescence complementation of fluorescent proteins, allow for the detection of protein-protein interactions in a homologous expression system, though many of these experiments have been performed subsequent to transient expression in protoplasts or epidermal cells of tobacco leaves [18,19].

Experimental data contribute to online data resources through collection, analysis and visualization, with computational methods even enabling predictions based on the deposited data. In fact, these methods have grown significantly in popularity over the past few years $[3,11,20,21]$. The entity of PPI within a living organism or particular cell is called the "interactome" [11,22-24]. Studying the interactome is crucial to understanding how cellular interactions are organized [11]. There is an increasing interest in this field, moving from the elucidation of genomes to working on proteomes and interactomes and respective databases [25-28]. With the help of computational methods, databases of interactomes for several species were launched (e.g., Escherichia coli [29-31], Saccharomyces cerevisiae [12,32-34], Drosophila melanogaster [35] as well as Caenorhabditis elegans [36]). In recent years, several approaches have dealt with the interactome of the plant Arabidopsis thaliana. This article aims at tracing and visualizing protein-protein interactions of $A$. thaliana and combines data from multiple databases within a network to reveal limitations and advantages in the current knowledge of the Arabidopsis interactome.

\section{Results}

According to TAIR, the genome of Arabidopsis thaliana contains 27,416 protein-coding genes (Table S3). The main portion of PPIs was identified in several databases, while an additional 920 PPIs were identified through a PubMed search for studies of interactions in Arabidopsis published over the last twenty years [37-161].

In total, 95,382 protein-protein interactions (PPI) were identified for 12,617 proteins, corresponding to approximately $46 \%$ of the number of genes coding for proteins (Tables S1 and S2). However, it should be considered that this number of genes does not account for splice variants. Co-expression data were available for 45,427 protein pairs, corresponding to $48 \%$ of the PPI in the network. In the IntAct-database we also found PPI-data for ten other plant species (including green algae Chlamydomonas reinhardtii) with comparatively low numbers of interactions (Table 1). Data from the STRING database were omitted due to the high fraction of predicted interactions [162]. 
Table 1. Protein-protein interactions of other plant species as deposited in IntAct.

\begin{tabular}{cc}
\hline Plant Species & Number of Interactions \\
\hline Arabidopsis thaliana & 81,399 \\
\hline Zea mays & 18 \\
Ricinus communis & 5 \\
Chlamydomonas reinhardtii & 17 \\
Glycine max & 46 \\
Solanum tuberosum & 3 \\
Oryza sativa & 348 \\
Nicotiana tomentosiformis & 3 \\
Solanum lycopersicum & 141 \\
Sorghum bicolor & 1 \\
Vitis vinifera & 1 \\
\hline
\end{tabular}

The consensus subcellular localization of SUBA was applied to have a first look at the contribution of compartments (Tables S4-S9). This revealed an enrichment of nuclear proteins $(26 \%$ to $34 \%)$ and a depletion of extracellular $(12 \%$ to $5 \%)$ and mitochondrial proteins $(9 \%$ to $6 \%$ ) (Figure 1$)$.
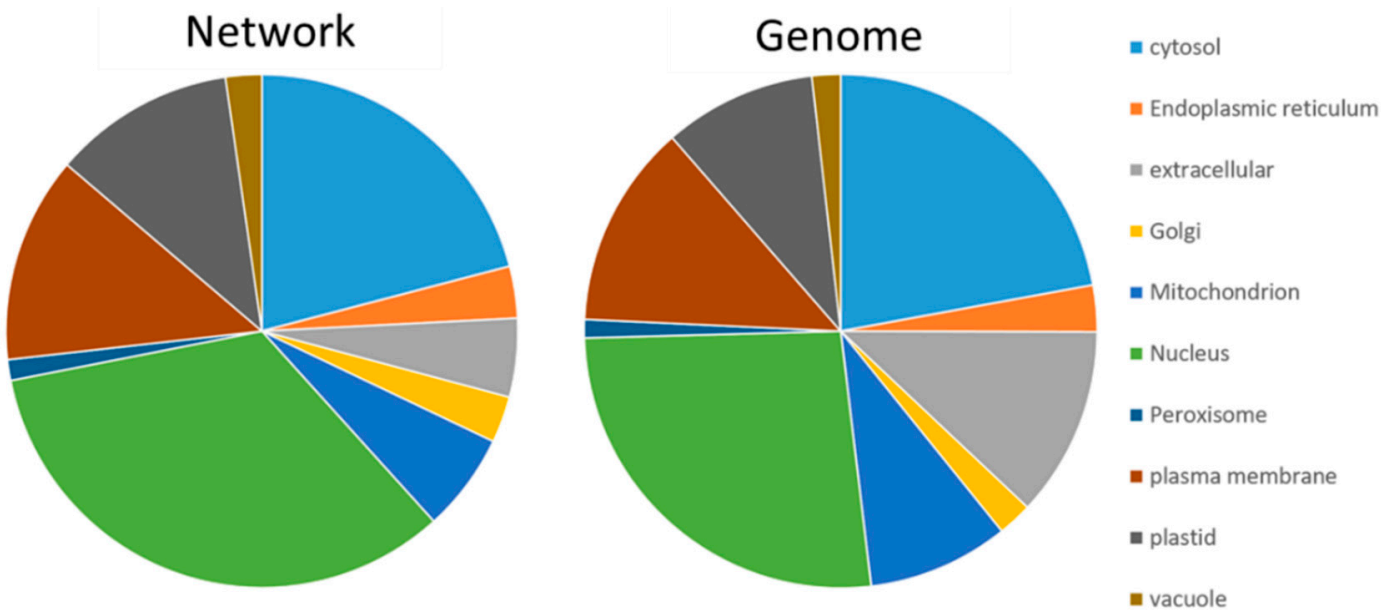

Figure 1. Subcellular distribution of proteins in the network and according to protein-coding AGI listed in the genome. The diagram is based on the consensus prediction provided by SUBA4. Nuclear proteins (green) were enriched in the network, and a depletion was visible for extracellular (grey) and mitochondrial proteins (blue).

The GO distribution confirmed the high content of nuclear proteins through enrichment of proteins involved in DNA-binding, transcription factor activity, nucleic acid binding, chromatin binding and transcription regulator activity (Figure 2).

Among the process GOs, a depletion of proteins involved in translation was obvious. Although one large-scale experiment focused on the interaction network of membrane proteins, we could only observe limited enrichment in plasma-membrane, ER, vacuolar or Golgi-proteins, which increased from $18 \%$ to $21 \%$. The process and function categories showed a consistently reduced abundance in the lipid metabolism process and lipidbinding function, as well as a reduced cell-cell signaling process and signaling receptor binding function (Figure 2). Reduction in the processes of translation regulator activity and translation was accompanied by a reduction in the RNA-binding function (Figure 2). 

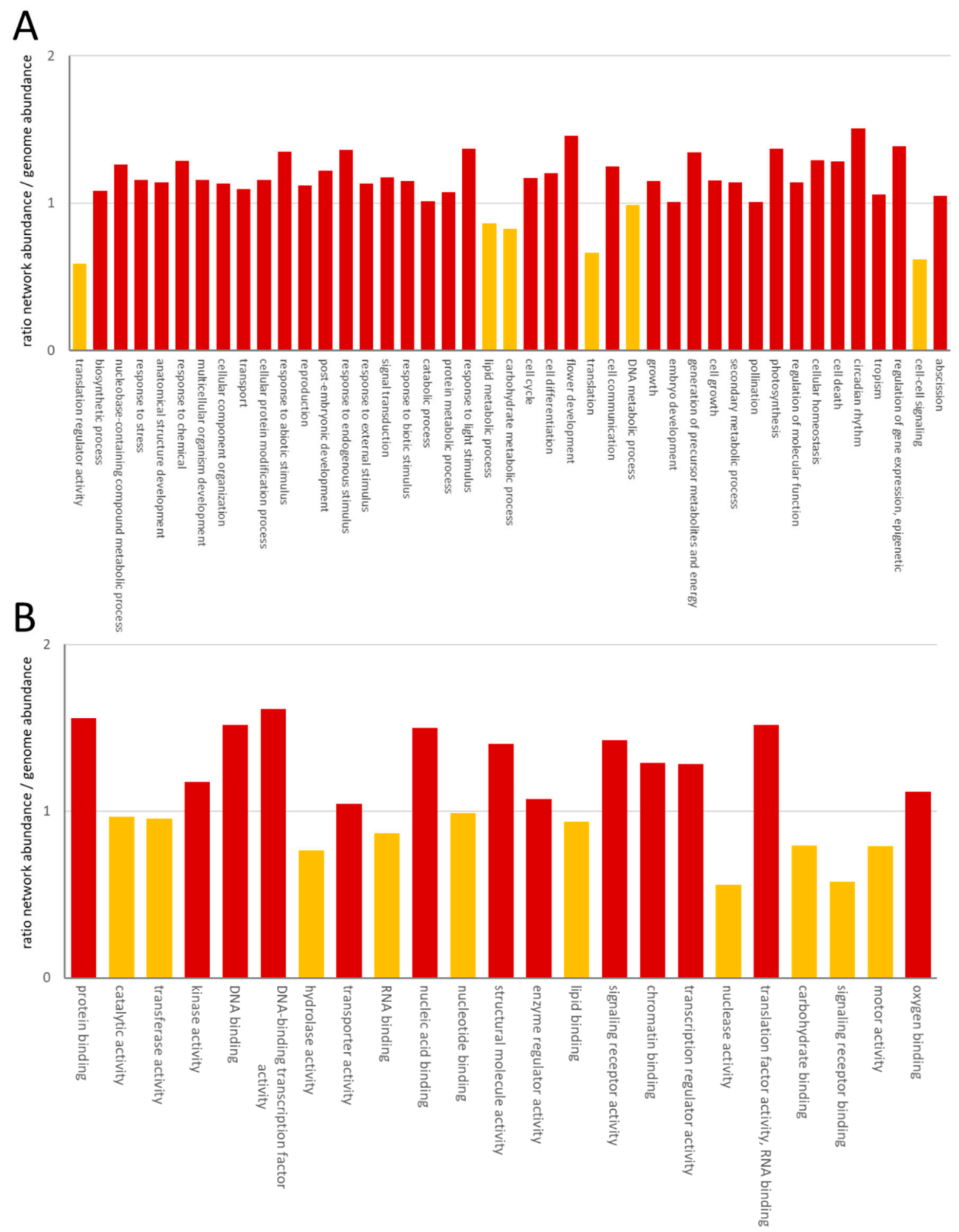

Figure 2. Enrichment of GO category process (A) and GO category function (B). The ratio has been calculated as the number of GOs in the network/the number of GOs of protein-coding genes in A. thaliana. GOs with a ratio $>1$ were considered as enriched in the network and labeled in red. Yellow columns correspond to ratios $<1$.

The network was constructed based on UniProt-IDs. For enhanced identification, commonly used AGIs were used as node labels, with the node color providing information on subcellular localization, which corresponds to the consensus localization provided by SUBA4 (Network S10). The network also contains experimental data on the subcellular localization, which were available for 9207 and 3162 proteins as mass spectroscopy and 
GFP data, respectively. Biochemical data were included as node attributes; for instance, TAIR provided the number of transmembrane helices for 725 proteins.

Subnetworks were defined by subcellular localization and GO-terms/gene descriptions and contain neighboring proteins/nodes of the selected nodes. Using this definition, ten subnetworks contain compartment-specific data. The respective number of interactions varied between the organelles. The largest subnetworks were associated with cytosolic and nuclear proteins (Table 2).

Table 2. Compartment-specific subnetworks.

\begin{tabular}{ccc}
\hline Network & Number of Interactions & Percentage \\
\hline Master network & 95,382 & $100 \%$ \\
\hline Cytosol & 7678 & $8 \%$ \\
Nucleus & 10,001 & $10 \%$ \\
Plastid & 4387 & $5 \%$ \\
Mitochondrion & 3672 & $4 \%$ \\
Peroxisome & 914 & $1 \%$ \\
ER & 2800 & $3 \%$ \\
Golgi & 2598 & $3 \%$ \\
Vacuole & 1957 & $2 \%$ \\
Plasma membrane & 6681 & $7 \%$ \\
Extracellular & 2838 & $3 \%$ \\
\hline
\end{tabular}

The organelle-subnetworks contain the following respective keyplayers: the ER network contains components of the COPII-vesicle coat (Sec12, Sec23/24, Sec13), protein sorting (cornichons and p24-proteins; Rer1) and proteins for protein biosynthesis, such as the Get-complex and ERAD-related proteins (IRE1, DERLIN1). The Golgi network comprises typical Xylosyl-, oligosaccharyl-, galacturonosyl-transferases, glucuronyltransferases, hydroxyproline O-galactosyltransferase, $\mathrm{N}$-acetylglucoseaminyl transferase I, Golgi-SNAREs Gos1 and Gos11. The vacuolar network contains seven V-ATPase subunits, a V-PPase and several other vacuolar transporters. Keyplayers of respiration were found in the mitochondria, including subunits of complexes I-IV and alternative oxidases, but also subunits of the TOM-complex, mitochondrial RNA-editing enzymes and mitochondrial ribosomal proteins. Catalases, catalase chaperones, photorespiratory enzymes and peroxin 11 are present in the peroxisomal network. The chloroplast network contains key players of photosynthesis, such as D1 and D2, CP43 and CP47; subunit IV of the cytochrome b6/f complex; PsaF, PsaG, PsaL, PsbP-proteins; PsbQ; ferredoxin-NADP(H) oxidoreductases and proteins of the light-harvesting complexes; but also cytosolic, nuclear and plasma membrane proteins. It is remarkable that a high content of plasma membrane and nuclear and cytosolic proteins was found in all organelle subnetworks. The nuclear network is characterized by DNAand RNA-modifying enzymes, such as polymerases, helicases, polyadenylation, ribonucleases, histones and enzymes of histone modification; such as E3 ubiquitin ligases, histone chaperones, histone methylation complex and histone acetyltransferases; while enzymes for deacetlyation, transcription factors and other transcription-regulating factors were also found in this subnetwork. Last but not least, a large variety of proteins were present in the cytosolic subnetwork, reflecting its involvement in many processes: components of the translational machinery (ribosomal proteins, elongation factors, chaperones); of signal transduction (calmodulins, thioredoxins, 14-3-3 proteins, kinases, phosphatases, enzymes of ubiquitinylation and sumoylation) and subunits of the proteasome contribute to the cytosolic network of protein-protein interactions.

The process-related subnetworks show a high contribution of protein biosynthesis (transcription and translation) to the number of protein-protein interactions, although the number of proteins with a function in translation was reduced in the network (Table 3). Conserved and fundamental processes, such as vesicle transport, glycolysis and respiration, were characterized by a surprisingly low level of representation in the network (Table 3). 
Table 3. Process-related subnetworks.

\begin{tabular}{ccc}
\hline Network & Number of Interactions & Percentage \\
\hline Master network & 95,382 & $100 \%$ \\
\hline Photosynthesis & 206 & $<1 \%$ \\
Transcription & 24,855 & $26 \%$ \\
Translation & 10,035 & $11 \%$ \\
Respiration & 273 & $<1 \%$ \\
Glycolysis & 197 & $<1 \%$ \\
\hline 14-3-3 network & 1419 & $1 \%$ \\
Calmodulin & 1056 & $1 \%$ \\
Thioredoxin & 1175 & $1 \%$ \\
Ubiquitin & 4705 & $5 \%$ \\
\hline SNARE & 1830 & $2 \%$ \\
Rab-GTPase & 619 & $<1 \%$ \\
Clathrin & 332 & $<1 \%$ \\
COP I & 232 & $<1 \%$ \\
Cornichon & 1089 & $1 \%$ \\
\hline
\end{tabular}

Some proteins showed an apparent sticky behavior with vastly more interaction counts than other protein family members. This includes the ER cargo receptor Cnih1 (AT3G12180), which interacts with 648 out of 662 Cnih-interaction partners, in comparison to its isoforms Cnih3 (AT1G62880) and Cnih4 (AT1G12390), which count eight and ten interacting proteins, respectively. Ubiquitin 3 (UBQ3) showed a similar behavior by interacting with 1317 proteins out of 2937 in the Ubiquitin subnetwork.

Looking at signaling subnetworks revealed organelle-specificity for thioredoxins with plasma membranes and plastidic clusters, while 14-3-3 proteins showed no organelle specificity (Figure 3). Furthermore, the 14-3-3 subnetwork contains primary active transporters such as proton pumps and calcium pumps, pointing to a role of 14-3-3 proteins in regulating calcium and $\mathrm{pH}$-homeostasis, as recently suggested for $\mathrm{pH}$ [163].

The SNARE network contains members of the tethering complex exocyst and cell plate assembly TRAPPII tethering factors, heavy chain subunits of clathrin-coated vesicles and SNAP25-like proteins, $\alpha$-SNAP proteins and members of the GET-complex, all of which are tightly connected to the function of SNAREs-despite an overrepresentation of plasma membrane proteins. The Ubiquitin subnetwork reflects the multiple functions and sticky behavior of Ubiquitin, with more than 4500 interactions in the network.

Next, the network was applied to gain new insights into the interactions of the plant proton-translocating ATPase of the vacuolar type (V-ATPase) and thereby to test the usefulness of the network for addressing biological questions. The V-ATPase is a multi-subunit proton pump, which transduces conformational alterations due to ATP-hydrolysis within the catalytic subunits VHA-A into rotation of the central stalk formed by VHA-D and -F. VHA-d transfers the rotation to the proteolipids VHA-c and VHA-c". These bear the proton binding sites, while half channels of VHA-a C-terminus serve as cytosolic proton inlet and luminal exhaust. VHA-a's N-terminal domain contributes to a stator structure together with VHA-C, $-\mathrm{E},-\mathrm{G}$ and $-\mathrm{H}$, stabilizing and fixing the catalytic head to the membrane [163]. For instance, the analysis aimed to provide evidence for the existence of a Golgi-dependent transport route to the vacuole and involvement of 14-3-3 proteins in V-ATPase regulation, which might indicate a light-dependent regulation, as reported for barley [164]. The V-ATPase subnetwork contained 448 interactions. Nearly all subunits were listed as interacting with the plasma membrane intrinsic proteins PIP1B, PIP2A, Ubiquitin UBQ3 and the ammonium transporter AMT1;3, probably originating from experiments that did not distinguish between the subunits. The provided subcellular localization was applied to omit proteins of the chloroplast and mitochondria from subsequent analyses. According to the previously mentioned ER-export and transport routes along the secretory pathway, the data revealed an interaction between VHA-e and the ER exit site cargo receptor Corni- 
chon 1 (Cnhi1) with a high co-expression level and between VHA-e1 and the ER to Golgi SNARE BET12. Interactions with SNAREs were also observed for VHA-A and the vacuolar SYP22, while the interaction of VHA-c and VAP27-1 links the V-ATPase subsector $V_{0}$ to ER-plasma membrane tethering, and VHA-D interacts with an adapter protein (AP19) of Clathrin-coated vesicles. On the regulatory level, interactions with 14-3-3 proteins were found for VHA-A and GRF3 as well as for VHA-B and GRF1 (Figure 4).
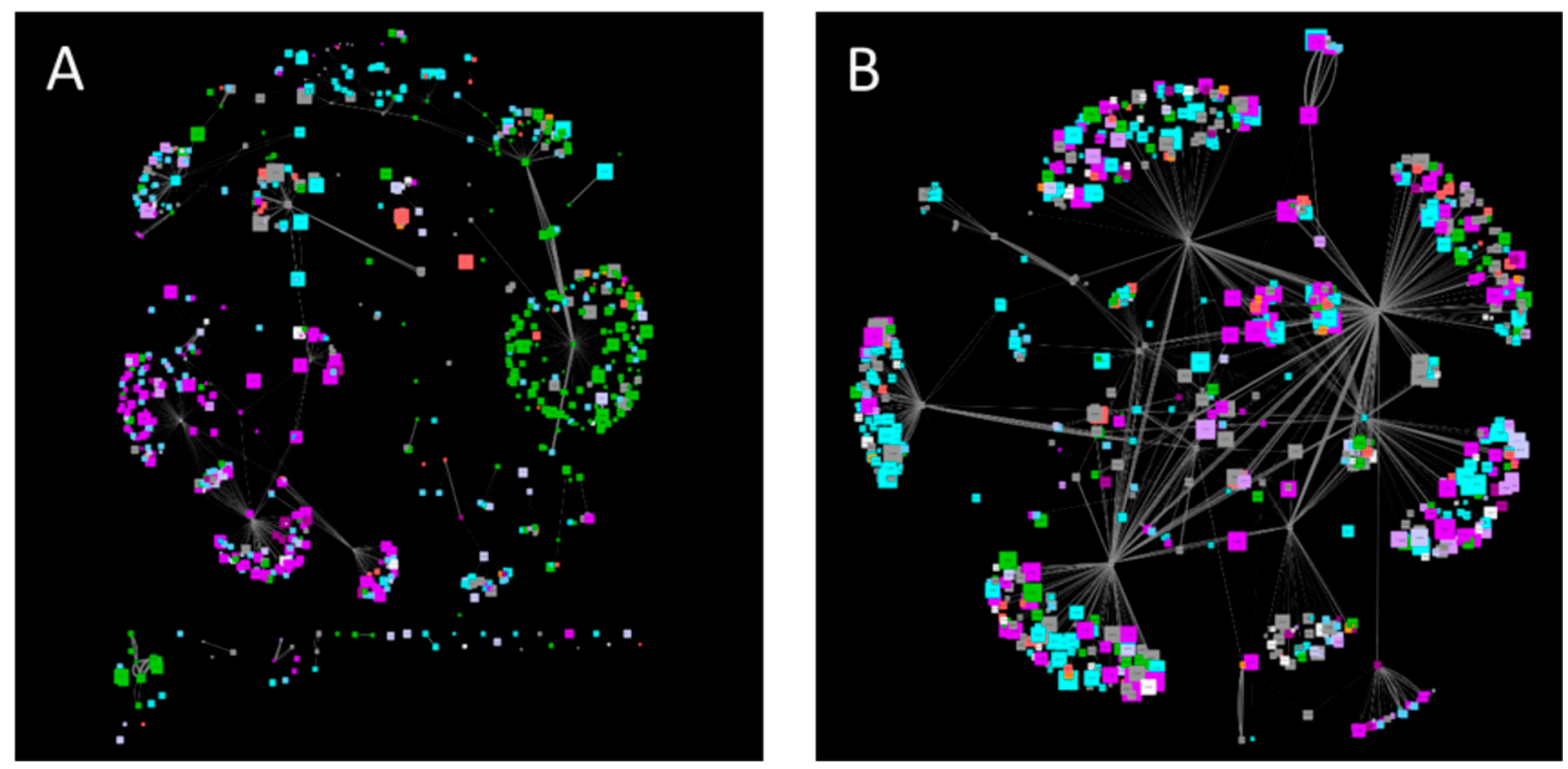

Figure 3. Subnetworks of Thioredoxins (A) and 14-3-3 proteins (B). Node color corresponds to subcellular localization (Cytosol—grey, nucleus—cyan, plastid—green, mitochondrionred, peroxisomes-orange, ER-light blue, Golgi-light purple, vacuole-dark purple, plasma membrane-purple, extracellular-white), node size indicates the molecular weight. Edge size displays co-expression strength.

Interaction between the hexokinase 1 and the glucose receptor RGS1 with VHA-B points to an energy-dependent regulation that acts directly on the head structure of the $\mathrm{V}$ ATPase, which catalyzes the ATP-hydrolysis. Furthermore, VHA-A and VHA-B (as well as VHA-E and G) are targets of salt overly sensitive 2 (SOS2), a Ca ${ }^{2+}$-sensor with a role in $\mathrm{K}^{+}$homeostasis and salinity. V-ATPases also interact with the Calmodulin-binding IDQ6, but with a low co-expression level and steroid-binding proteins such as MSBP2 and RBL11. The nucleoside diphosphate kinase NDPK1A, which modulates the auxin-transport, interacts with VHA-c, while the soluble kinase Without No Lysine 8 (WNK8) interacts with VHA-C. Interestingly, VHA-C binds to APG5, which is responsive to nitrogen starvation, and to the nitrate reductase NIA1. A couple of transcription factors were reported to interact with V-ATPase subunits, including three members of the MYB-family, two of the TCP-family, two of the NAC-family, UNE12, scarecrow-like 3, transparent testa 1 and WRKY60.

The interaction of V-ATPase subunits and proteins involved in cell wall synthesis, such as EMB3135, TBL18, ECH and YIP4B, point to a function of V-ATPase in cell wall synthesis. Here, V-ATPase joins the complex of ECH and YIP4B at the TGN via VHA-a and VHA-c.

The interaction between V-ATPase and other transporters is also apparent, where the interaction of the phosphate transporter PHT3 and the phosphate-starvation-induced IPS2 with $\mathrm{V}_{0}$-subunits might correspond to the terminal signal-transduction (Figure 4). 


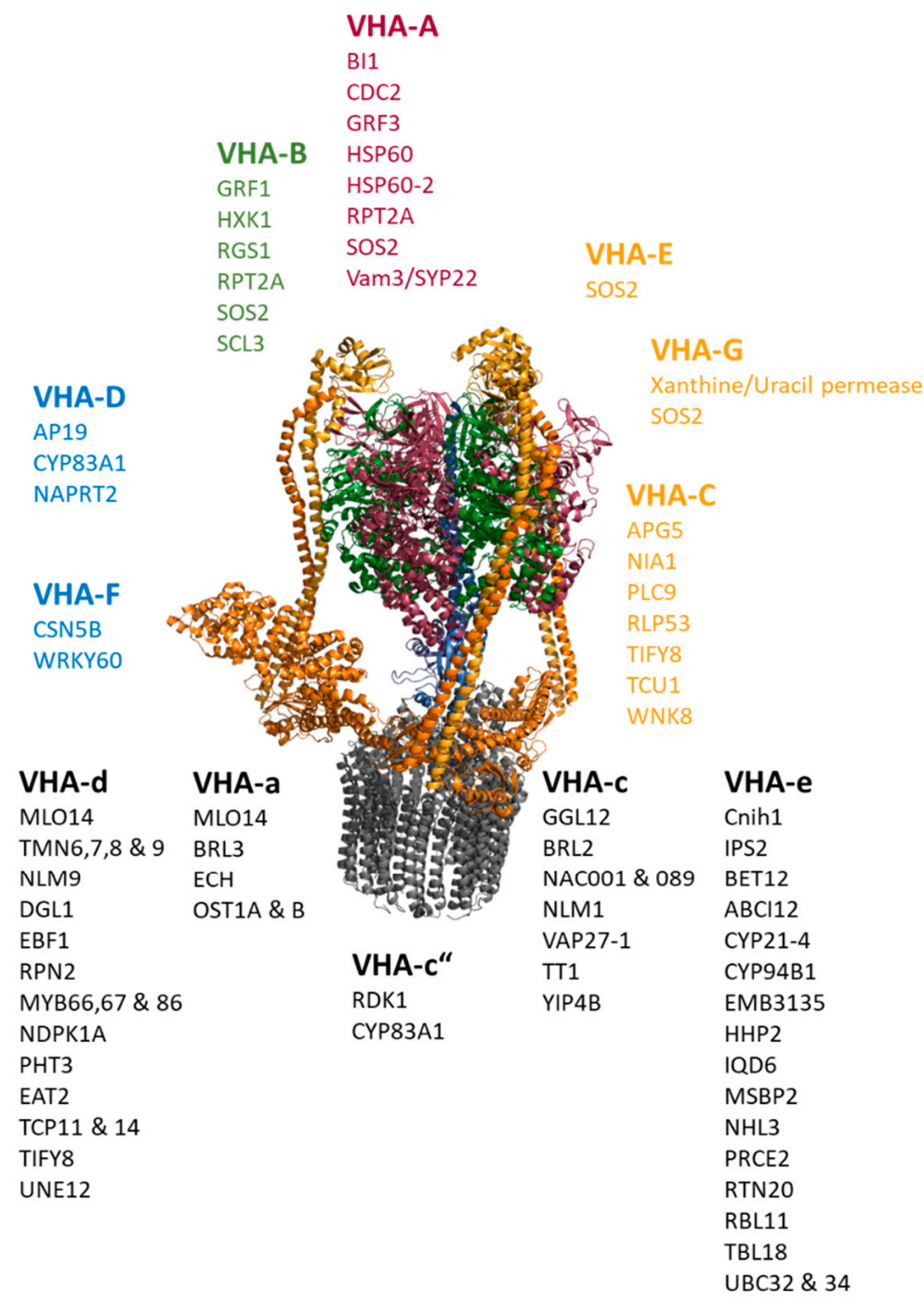

Figure 4. Protein-protein interactions of V-ATPase subunits. The catalytic head comprises VHA-A (red) and VHA-B (green). Subunits of the peripheral stalk (VHA-C, VHA-E, VHA-G, VHA-H) are given in orange-yellow, and the central stalk (VHA-D, VHA-F) is shown in blue. The membrane integral sector $\mathrm{V}_{0}$ consists of VHA-a, the proteolipids VHA-c and VHA-c", the bearing VHA-d and the subunit VHA-e. A selection of interacting proteins is given per subunits, regardless of the isoform.

\section{Discussion}

Data in the databases are dominated by yeast-2-hybrid experiments, and the main portion has been contributed by only a few publications (Figure 5): the share of yeast-2-hybrid experiments is approximately one-third, and four publications account for more than half of the data. This creates a bias in the data, which results from the aim of the studies and their methodical limitations. For instance, one of the dominant studies involved screening for transcription factor interactions [165], while another focused on interactions of membrane proteins [166] so that the observed enrichment of nuclear proteins and plasma membrane protein interactions is plausible. 

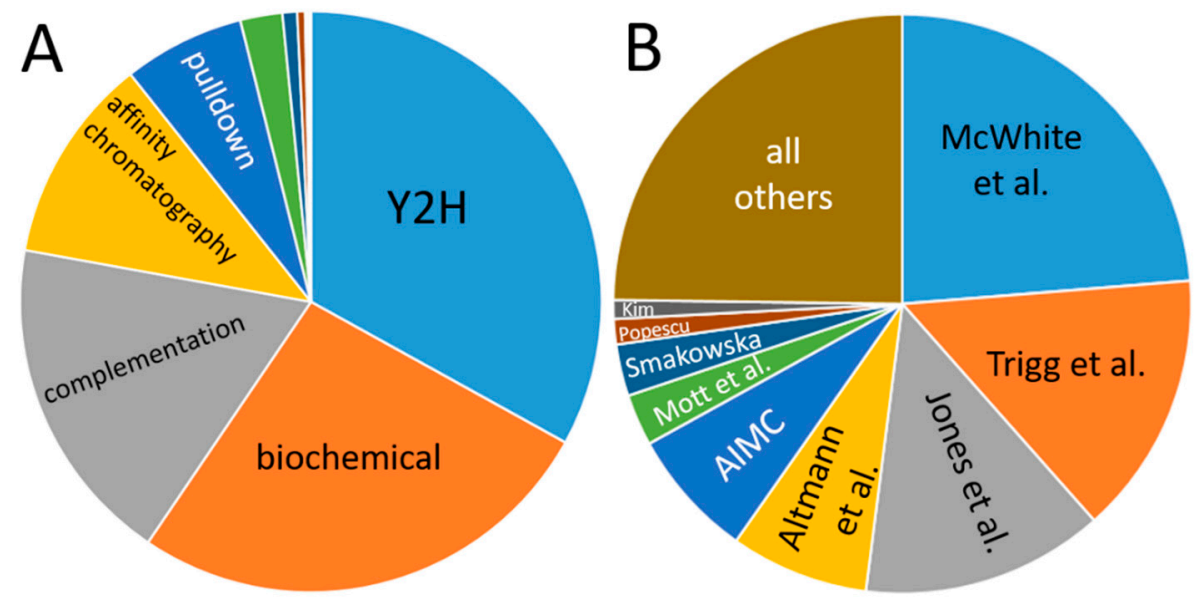

Figure 5. Contribution of individual methods (A) and publications (B) to the databases. (A) "Biochemical" denominates data from co-fractionation/mass spectroscopy (CF/MS) [167]. Enzymatic studies (green), Förster resonance energy transfer (dark blue), genetic interference (brown), X-ray experiments, imaging techniques and FarWestern contribute a comparatively low amount of data. (B) Publications are given by the name of the first author; Smakowska corresponds to Smakowska-Luzan [165,166,168-174].

The experimental design has an additional impact on the subcellular localization of the proteins in the network: yeast-2-hybrid relies on protein-protein interactions in the nucleus or applies artificial nuclear localization sequences. The mating-based split-Ubiquitin system works for proteins with cytosolic C-termini in particular for the C-terminal half of Ubiquitin due to the fusion with a transcription factor, which is released by Ubiquitin-dependent proteases. The N-terminal half of Ubiquitin (Nub) can be fused to either a cytosolic $\mathrm{N}$ or C-terminus [175]. For instance, mitochondrial proteins cannot be addressed by these methods, potentially contributing to a low representation of mitochondrial proteins in the network.

Another consideration applies to the probability of an interaction; complementation assays such as bimolecular fluorescence complementation and mbSUS are often performed in heterologous expression systems, partially with strong promoters. This uncouples protein-protein interactions from their spatial and temporal specificity in the plant. The specificity is widely ensured by pulldown experiments, co-immunoprecipitations, affinity chromatography and genetic interference, since proteins are mostly under control under their endogenous promoters and in their native environment. However, to compensate for the problem of low specificity and the risk of false-positive interactions in the network, the data were supplemented by the co-expression lsMR-values as a measure of probability. The higher the co-expression, the higher the probability of a protein-protein interaction in the plants. Low co-expression might then be an indicator of false-positive interactions. However, many proteins with related functions were found in the expected and typical clusters, demonstrating the value of the databases for proposing new hypotheses. The visible crosstalk between signaling pathways, such as 14-3-3-protein-mediated signaling and calcium signaling, or the control of proton pumps by 14-3-3 proteins, reveals the complexity of regulation and signal transduction in the plant.

Interaction between V-ATPase subunit VHA-A and 14-3-3 proteins has been shown to be blue-light-dependent in barley [164], and the observed interaction of 14-3-3 proteins and VHA-A/-B points to similar regulation in A. thaliana, which links the V-ATPase activity to daylight. In this context, the observed interplay of V-ATPase and nitrogen assimilation and availability fits well into light-dependent activation. A glucose-dependent regulation by reversible dissociation of the $\mathrm{V}$-ATPase complex has been described for the yeast and the mammalian V-ATPase [176], but could not be observed in plants [177]. Instead, VHA-B1 was reported to interact with hexokinase 1 in the nucleus as part of the glucose-dependent gene-regulation complex [178]. However, this interaction was observed for VHA-B1 in 
the absence of other VHA-subunits, describing a moon-lighting function of VHA-B1. Interestingly, interaction with glycolytic aldolase was not found in the dataset, though its regulatory function has been described for the V-ATPase in rice [179]. The interaction with the glucose receptor RGS1 might be an alternate way to sense the glucose level in order to regulate the V-ATPase and its ATP consumption.

On the cell-biological level, the data show a clear linkage to cell wall synthesis and is in good agreement with the previously reported cell wall defects of V-ATPase knock out lines affected in the TGN [180]. Actually, the PPI-data indicate a contribution of V-ATPase to the TGN-located complex of ECHIDNA and the YPT/Rab-interacting protein 4B, which is essential for the secretion of cell wall saccharides.

Last but not least, the mechanism of the transport of V-ATPases is less understood. $\mathrm{V}_{0}$-subunits such as VHA-a and VHA-c were observed to be transported on a fast track from the ER to the vacuole and thus bypassed the Golgi and TGN, while the $\mathrm{V}_{1}$-subunit VHA-E followed the canonical secretory pathway [181-183]. The interaction with components of the ER to Golgi transport, such as Cnih1 and Bet12, supports the finding of COP II-dependent transport without ruling out an alternate direct pathway to the vacuole. Furthermore, the interaction found between V-ATPase subunit VHA-c and VAP-27-1 even links the V-ATPase to contact sites between the ER and the plasma membrane [184].

\section{Materials and Methods}

Databases-all gene descriptions and GO-terms were bulk downloads from The Arabidopsis Information Resource (TAIR, www.arabidopsis.org, accessed on 16 July 2021). First, a list of all Arabidopsis genome identifiers (AGI) was downloaded from TAIR and used for interaction searches in IntAct and Biogrid. If required, UniProt-IDs were mapped to AGI using the UniProt ID-mapping (https: / / www.uniprot.org/uploadlists/, accessed on 16 July 2021).

PubMed (https:/ / pubmed.ncbi.nlm.nih.gov/, accessed on 16 July 2021) and Web of Science (https: / / www.webofscience.com/wos/woscc/basic-search, accessed on 16 July 2021) were applied to screen the literature for protein-protein interactions. Keywords were Arabidopsis thaliana, protein interaction and one of the following methods: yeast-2-hybrid, mating-based split-Ubiquitin system, co-immunoprecipitation, TAP-tag, BiFC. The time span of publication dates was 2002-2021.

Data on subcellular localization were obtained from SUBA4 (https://suba.live, accessed on 16 July 2021). Co-expression data came from ATTED II (https://atted.jp, accessed on 16 July 2021). Data were obtained 21 July 2021.

Networks-required data sheets were created using Microsoft Excel (Tables S1-S9); all networks were designed using Cytoscape version 3.8.2 (Network S10). Simple grid layout was chosen for the entire master network, compound spring embedder layout for subnetworks. LsMR-values were chosen as edge-attributes; all other data were node attributes. Cytoscape styles were defined to express the co-expression, subcellular localization and molecular weight (Table 4). 
Table 4. List of applied Cytoscape styles.

\begin{tabular}{|c|c|c|c|}
\hline Target of Style & Attribute Group & Attribute & Style \\
\hline Node & $\begin{array}{l}\text { Subcellular localization } \\
\text { (discrete mapping) }\end{array}$ & $\begin{array}{c}\text { Cytosol } \\
\text { Nucleus } \\
\text { Plastid } \\
\text { Mitochondrion } \\
\text { Peroxisomes } \\
\text { ER } \\
\text { Golgi } \\
\text { Vacuole } \\
\text { Plasma membrane } \\
\text { extracellular }\end{array}$ & $\begin{array}{c}\text { Grey } \\
\text { Cyan } \\
\text { green } \\
\text { Red } \\
\text { Orange } \\
\text { Light blue } \\
\text { Light purple } \\
\text { Dark purple } \\
\text { Purple } \\
\text { White }\end{array}$ \\
\hline Node & $\begin{array}{c}\text { Protein properties } \\
\text { (continuous mapping) }\end{array}$ & Molecular weight & Node size \\
\hline Edge & $\begin{array}{c}\text { Co-expression } \\
\text { (continuous mapping) }\end{array}$ & LsMR & Line size \\
\hline
\end{tabular}

All collected data are given in Excel sheets as Supplementary Materials.

\section{Conclusions}

The dataset contains known protein-protein interactions in A. thaliana, which were combined with expression, subcellular localization and GO-association data. Interactions can be screened by gene identifiers and found pairs evaluated based on co-expression and localization data to estimate the probability of interaction. The exemplary analysis of the V-ATPase revealed interactions that were well described in the literature but also others that have not been considered before. Such novel interactions might be worthwhile to investigate further in order to open new perspectives on the characterization of a protein or complex.

Supplementary Materials: The following are available online at https: / www.mdpi.com/article/ 10.3390/plants11030350/s1, Table S1: node attributes.xlsx, Table S2: edge attributes.xlsx, Table S3: list of AGIs.xlsx, Tables S4-S9: SUBA4-data, Network S10: Cytoscape network file Arabidopsis PPI network.cys.

Author Contributions: Conceptualization, T.S.; methodology, T.S., M.Y. and M.P.; data curation, T.S., M.Y. and M.P.; writing—original draft preparation, T.S. and M.Y.; writing-review and editing, T.S.; supervision, T.S.; project administration, T.S.; funding acquisition, T.S. All authors have read and agreed to the published version of the manuscript.

Funding: This research received no external funding besides Bielefeld University (see Acknowledgments).

Institutional Review Board Statement: Not applicable.

Informed Consent Statement: Not applicable.

Data Availability Statement: No new data were created or analyzed in this study. The data presented in this study are available in supplementary material here.

Acknowledgments: We are grateful to Helen Nicol Krahn, Nicole Paschen, Timo Denecke, Bonnie Hohnen, Annika Larissa Hallau, Sergej Ljalin, Maria Kampling and Martha Charlotte-Elisabeth Keitel for their support with the co-expression analysis. This work has been funded by Bielefeld University. We acknowledge support for the publication costs by the Open Access Publication Fund of Bielefeld University.

Conflicts of Interest: The authors declare no conflict of interest. The funders had no role in the design of the study; in the collection, analyses, or interpretation of data; in the writing of the manuscript, or in the decision to publish the results. 


\section{References}

1. Zhang, Y.; Lin, H.; Yang, Z.; Wang, J.; Liu, Y.; Sang, S. A method for predicting protein complex in dynamic PPI networks. BMC Bioinform. 2016, 17 (Suppl. S7), 229. [CrossRef] [PubMed]

2. Las Rivas, J.; de Fontanillo, C. Protein-protein interactions essentials: Key concepts to building and analyzing interactome networks. PLoS Comput. Biol. 2010, 6, e1000807. [CrossRef] [PubMed]

3. Li, X.; Wu, M.; Kwoh, C.-K.; Ng, S.-K. Computational approaches for detecting protein complexes from protein interaction networks: A survey. BMC Genom. 2010, 11 (Suppl. S1), S3. [CrossRef] [PubMed]

4. Ashburner, M.; Ball, C.A.; Blake, J.A.; Botstein, D.; Butler, H.; Cherry, J.M.; Davis, A.P.; Dolinski, K.; Dwight, S.S.; Eppig, J.T.; et al. Gene ontology: Tool for the unification of biology. The Gene Ontology Consortium. Nat. Genet. 2000, 25, 25-29. [CrossRef]

5. Braun, P.; Gingras, A.C. History of protein-protein interactions: From egg-white to complex networks. Proteomics 2012, 12 [CrossRef] [PubMed]

6. Caffarri, S.; Tibiletti, T.; Jennings, R.C.; Santabarbara, S. A comparison between plant photosystem I and photosystem II architecture and functioning. Curr. Protein Pept. Sci. 2014, 15, 296-331. [CrossRef] [PubMed]

7. Dudkina, N.V.; Eubel, H.; Keegstra, W.; Boekema, E.J.; Braun, H.-P. Structure of a mitochondrial supercomplex formed by respiratory-chain complexes I and III. Proc. Natl. Acad. Sci. USA 2005, 102, 3225-3229. [CrossRef]

8. Mohanta, T.K.; Yadav, D.; Khan, A.L.; Hashem, A.; Abd Allah, E.F.; Al-Harrasi, A. Molecular Players of EF-hand Containing Calcium Signaling Event in Plants. Int. J. Mol. Sci. 2019, 20, 1476. [CrossRef]

9. Denison, F.C.; Paul, A.L.; Zupanska, A.K.; Ferl, R.J. 14-3-3 proteins in plant physiology. Semin. Cell Dev. Biol. 2011, 22, 720-727. [CrossRef]

10. Geigenberger, P.; Thormählen, I.; Daloso, D.M.; Fernie, A.R. The Unprecedented Versatility of the Plant Thioredoxin System. Plant Sci. 2017, 22, 249-262. [CrossRef]

11. Koh, G.C.K.W.; Porras, P.; Aranda, B.; Hermjakob, H.; Orchard, S.E. Analyzing protein-protein interaction networks J. Proteome Res. 2012, 11, 2014-2031. [CrossRef] [PubMed]

12. Uetz, P.; Giot, L.; Cagney, G.; Mansfield, T.A.; Judson, R.S.; Knight, J.R.; Lockshon, D.; Narayan, V.; Srinivasan, M.; Pochart, P.; et al. A comprehensive analysis of protein-protein interactions in Saccharomyces cerevisiae. Nature 2000, 403, 623-627. [CrossRef] [PubMed]

13. Gavin, A.-C.; Bösche, M.; Krause, R.; Grandi, P.; Marzioch, M.; Bauer, A.; Schultz, J.; Rick, J.M.; Michon, A.-M.; Cruciat, C.-M.; et al. Functional organization of the yeast proteome by systematic analysis of protein complexes. Nature 2002, 415, 141-147. [CrossRef] [PubMed]

14. Brückner, A.; Polge, C.; Lentze, N.; Auerbach, D.; Schlattner, U. Yeast Two-Hybrid, a powerful tool for systems biology. Int. J. Mol. Sci. 2009, 10, 2763-2788. [CrossRef]

15. Grefen, C.; Lalonde, S.; Obrdlik, P. Split-Ubiquitin system for identifying protein-protein interactions in membrane and full-length proteins. Curr. Protoc. Neurosci. 2007, 5, 5-27. [CrossRef]

16. Lin, J.S.; Lai, E.M. Protein-protein interactions: Co-immunoprecipitation. Methods Mol. Biol. 2017, 1615, 211-219. [CrossRef]

17. Van Leene, J.; Witters, E.; Inzé, D.; De Jaeger, G. Boosting tandem affinity purification of plant protein complexes. Trends Plant Sci. 2008, 13, 517-520. [CrossRef]

18. Müller, S.M.; Galliardt, H.; Schneider, J.; Barisas, B.G.; Seidel, T. Quantification of Förster resonance energy transfer by monitoring sensitized emission in living plant cells. Front. Plant Sci. 2013, 4, 413. [CrossRef]

19. Kudla, J.; Bock, R. Lighting the way to protein-protein interactions. recommendations on best practices for bimolecular complementation analyses. Plant Cell 2016, 28, 1002-1008. [CrossRef]

20. Bader, G.D.; Hogue, C.W.V. An automated method for finding molecular complexes in large protein interaction networks BMC Bioinform. 2003, 4, 2. [CrossRef]

21. Chen, B.; Shi, J.; Zhang, S.; Wu, F.-X. Identifying protein complexes in protein-protein interaction networks by using clique seeds and graph entropy. Proteomics 2013, 13, 269-277. [CrossRef] [PubMed]

22. Dostie, J.; Ferraiuolo, M.; Pause, A.; Adam, S.A.; Sonenberg, N. A novel shuttling protein, 4E-T, mediates the nuclear import of the mRNA 5' cap-binding protein, eIF4E. EMBO J. 2000, 19, 3142-3156. [CrossRef] [PubMed]

23. Cusick, M.E.; Klitgord, N.; Vidal, M.; Hill, D.E. Interactome: Gateway into systems biology. Hum. Mol. Genet. 2005, 14, R171-R181. [CrossRef] [PubMed]

24. Wang, L.; Eftekhari, P.; Schachner, D.; Ignatova, I.D.; Palme, V.; Schilcher, N.; Ladurner, A.; Heiss, E.H.; Stangl, H.; Dirsch, V.M.; et al. Novel interactomics approach identifies ABCA1 as direct target of evodiamine, which increases macrophage cholesterol efflux. Sci. Rep. 2018, 8, 11061. [CrossRef] [PubMed]

25. Ghadie, M.A.; Coulombe-Huntington, J.; Xia, Y. Interactome evolution: Insights from genome-wide analyses of protein-protein interactions. Curr. Opin. Struct. Biol. 2018, 50, 42-48. [CrossRef] [PubMed]

26. Kuhn, M.; Szklarczyk, D.; Franceschini, A.; von Mering, C.; Jensen, L.J.; Bork, P. STITCH 3: Zooming in on protein-chemical interactions. Nucleic Acids Res. 2012, 40, D876-D880. [CrossRef] [PubMed]

27. Rao, V.S.; Srinivas, K.; Sujini, G.N.; Kumar, G.N.S. Protein-protein interaction detection: Methods and analysis. Int. J. Proteom. 2014, 2014, 147648. [CrossRef]

28. Salwinski, L.; Miller, C.S.; Smith, A.J.; Pettit, F.K.; Bowie, J.U.; Eisenberg, D. The Database of Interacting Proteins: 2004 update. Nucleic Acids Res. 2004, 32, D449-D451. [CrossRef] 
29. Butland, G.; Peregrín-Alvarez, J.M.; Li, J.; Yang, W.; Yang, X.; Canadien, V.; Starostine, A.; Richards, D.; Beattie, B.; Krogan, N.; et al. Interaction network containing conserved and essential protein complexes in Escherichia coli. Nature 2005, 433, 531-537. [CrossRef]

30. Butland, G.; Zhang, J.W.; Yang, W.; Sheung, A.; Wong, P.; Greenblatt, J.F.; Emili, A.; Zamble, D.B. Interactions of the Escherichia coli hydrogenase biosynthetic proteins: HybG complex formation. FEBS Lett. 2006, 580, 677-681. [CrossRef]

31. Arifuzzaman, M.; Maeda, M.; Itoh, A.; Nishikata, K.; Takita, C.; Saito, R.; Ara, T.; Nakahigashi, K.; Huang, H.-C.; Hirai, A.; et al. Large-scale identification of protein-protein interaction of Escherichia coli K-12. Genome Res. 2006, 16, 686-691. [CrossRef] [PubMed]

32. Yu, H.; Braun, P.; Yildirim, M.A.; Lemmens, I.; Venkatesan, K.; Sahalie, J.; Hirozane-Kishikawa, T.; Gebreab, F.; Li, N.; Simonis, N.; et al. High-Quality Binary Protein Interaction Map of the Yeast Interactome Network. Science 2008, 322, 104-110. [CrossRef] [PubMed]

33. Krogan, N.J.; Cagney, G.; Yu, H.; Zhong, G.; Guo, X.; Ignatchenko, A.; Li, J.; Pu, S.; Datta, N.; Tikuisis, A.P.; et al. Global landscape of protein complexes in the yeast Saccharomyces cerevisiae. Nature 2006, 440, 637-643. [CrossRef] [PubMed]

34. Ho, Y.; Gruhler, A.; Heilbut, A.; Bader, G.D.; Moore, L.; Adams, S.-L.; Millar, A.; Taylor, P.; Bennett, K.; Boutilier, K.; et al. Systematic identification of protein complexes in Saccharomyces cerevisiae by mass spectrometry. Nature 2002, 415, 180-183. [CrossRef]

35. Giot, L. A Protein Interaction Map of Drosophila melanogaster. Science 2003, 302, 1727-1736. [CrossRef]

36. Reboul, J.; Vaglio, P.; Rual, J.-F.; Lamesch, P.; Martinez, M.; Armstrong, C.M.; Li, S.; Jacotot, L.; Bertin, N.; Janky, R.; et al. C. elegans ORFeome version 1.1: Experimental verification of the genome annotation and resource for proteome-scale protein expression. Nat. Genet. 2003, 34, 35-41. [CrossRef]

37. Han, L.; Mason, M.; Risseeuw, E.P.; Crosby, W.L.; Somers, D.E. Formation of an SCF(ZTL) complex is required for proper regulation of circadian timing. Plant J. 2004, 40, 291-301. [CrossRef]

38. Berger, N.; Vignols, F.; Przybyla-Toscano, J.; Roland, M.; Rofidal, V.; Touraine, B.; Zienkiewicz, K.; Couturier, J.; Feussner, I.; Santoni, V.; et al. Identification of client iron-sulfur proteins of the chloroplastic NFU2 transfer protein in Arabidopsis thaliana. J. Exp. Bot. 2020, 71, 4171-4187. [CrossRef]

39. Shin, J.; Jeong, G.; Park, J.Y.; Kim, H.; Lee, I. MUN (Meristem Unstructured), encoding a SPC24 homolog of NDC80 kinetochore complex, affects development through cell division in Arabidopsis thaliana. Plant J. 2018, 93. [CrossRef]

40. Abdeeva, I.A.; Pogorelko, G.V.; Maloshenok, L.G.; Mokrykova, M.V.; Fursova, O.V.; Bruskin, S.A. Search for Partner Proteins of A. thaliana Immunophilins Involved in the Control of Plant Immunity. Molecules 2018, 23, 953. [CrossRef]

41. Aboulela, M.; Tanaka, Y.; Nishimura, K.; Mano, S.; Kimura, T.; Nakagawa, T. A dual-site gateway cloning system for simultaneous cloning of two genes for plant transformation. Plasmid 2017, 92, 1-11. [CrossRef] [PubMed]

42. Bai, F.; Matton, D.P. The Arabidopsis Mitogen-Activated Protein Kinase Kinase Kinase 20 (MKKK20) C-terminal domain interacts with MKK3 and harbors a typical DEF mammalian MAP kinase docking site. Plant Signal. Behav. 2018, 13, e1503498. [CrossRef] [PubMed]

43. Bassard, J.-E.; Richert, L.; Geerinck, J.; Renault, H.; Duval, F.; Ullmann, P.; Schmitt, M.; Meyer, E.; Mutterer, J.; Boerjan, W.; et al Protein-protein and protein-membrane associations in the lignin pathway. Plant Cell 2012, 24, 4465-4482. [CrossRef] [PubMed]

44. Bobik, K.; Fernandez, J.C.; Hardin, S.R.; Ernest, B.; Ganusova, E.E.; Staton, M.E.; Burch-Smith, T.M. The essential chloroplast ribosomal protein uL15c interacts with the chloroplast RNA helicase ISE2 and affects intercellular trafficking through plasmodesmata. New Phytol. 2019, 221, 850-865. [CrossRef] [PubMed]

45. Bogamuwa, S.; Jang, J.-C. Plant Tandem CCCH Zinc Finger Proteins Interact with ABA, Drought, and Stress Response Regulators in Processing-Bodies and Stress Granules. PLoS ONE 2016, 11, e0151574. [CrossRef]

46. Bonsegna, S.; Slocombe, S.P.; de Bellis, L.; Baker, A. AtLACS7 interacts with the TPR domains of the PTS1 receptor PEX5. Arch. Biochem. Biophys. 2005, 443, 74-81. [CrossRef]

47. Boruc, J.; Deng, X.; Mylle, E.; Besbrugge, N.; van Durme, M.; Demidov, D.; Tomaštíková, E.D.; Tan, T.-R.C.; Vandorpe, M.; Eeckhout, D.; et al. TPX2-LIKE PROTEIN3 Is the Primary Activator of $\alpha$-Aurora Kinases and Is Essential for Embryogenesis. Plant Physiol. 2019, 180, 1389-1405. [CrossRef]

48. Brasil, J.N.; Cabral, L.M.; Eloy, N.B.; Primo, L.M.F.; Barroso-Neto, I.L.; Grangeiro, L.P.P.; Gonzalez, N.; Inzé, D.; Ferreira, P.C.G.; Hemerly, A.S. AIP1 is a novel Agenet/Tudor domain protein from Arabidopsis that interacts with regulators of DNA replication, transcription and chromatin remodeling. BMC Plant Biol. 2015, 15, 270. [CrossRef]

49. Bueso, E.; Rodriguez, L.; Lorenzo-Orts, L.; Gonzalez-Guzman, M.; Sayas, E.; Muñoz-Bertomeu, J.; Ibañez, C.; Serrano, R.; Rodriguez, P.L. The single-subunit RING-type E3 ubiquitin ligase RSL1 targets PYL4 and PYR1 ABA receptors in plasma membrane to modulate abscisic acid signaling. Plant J. 2014, 80, 1057-1071. [CrossRef]

50. Cerveau, D.; Kraut, A.; Stotz, H.U.; Mueller, M.J.; Couté, Y.; Rey, P. Characterization of the Arabidopsis thaliana 2-Cys peroxiredoxin interactome. Plant Sci. 2016, 252, 30-41. [CrossRef]

51. Chang, J.; Clay, J.M.; Chnag, C. Association of cytochrome b5 with ETR1 ethylene receptor signaling through RTE1 in Arabidopsis. Plant J. 2014, 77, 558-567. [CrossRef] [PubMed]

52. Chang, H.-C.; Tsai, M.-C.; Wu, S.-S.; Chang, I.-F. Regulation of ABI5 expression by ABF3 during salt stress responses in Arabidopsis thaliana. Bot. Stud. 2019, 60, 16. [CrossRef] [PubMed] 
53. Chen, K.; Fan, B.; Du, L.; Chen, Z. Activation of hypersensitive cell death by pathogen-induced receptor-like protein kinases from Arabidopsis. Plant Mol. Biol. 2004, 56, 271-283. [CrossRef] [PubMed]

54. Chou, Y.-H.; Pogorelko, G.; Young, Z.T.; Zabotina, O.A. Protein-protein interactions among xyloglucan-synthesizing enzymes and formation of Golgi-localized multiprotein complexes. Plant Cell Physiol. 2015, 56, 255-267. [CrossRef] [PubMed]

55. Cook, G.S.; Grønlund, A.L.; Siciliano, I.; Spadafora, N.; Amini, M.; Herbert, R.J.; Bitonti, M.B.; Graumann, K.; Francis, D.; Rogers, H.J. Plant WEE1 kinase is cell cycle regulated and removed at mitosis via the $26 \mathrm{~S}$ proteasome machinery. J. Exp. Bot. 2013, 64, 2093-2106. [CrossRef] [PubMed]

56. Cuéllar Pérez, A.; Nagels Durand, A.; Vanden Bossche, R.; de Clercq, R.; Persiau, G.; van Wees, S.C.M.; Pieterse, C.M.J.; Gevaert, K.; de Jaeger, G.; Goossens, A.; et al. The non-JAZ TIFY protein TIFY8 from Arabidopsis thaliana is a transcriptional repressor. PLoS ONE 2014, 9, e84891. [CrossRef] [PubMed]

57. Czarnocka, W.; van der Kelen, K.; Willems, P.; Szechyńska-Hebda, M.; Shahnejat-Bushehri, S.; Balazadeh, S.; Rusaczonek, A.; Mueller-Roeber, B.; van Breusegem, F.; Karpiński, S. The dual role of LESION SIMULATING DISEASE 1 as a condition-dependent scaffold protein and transcription regulator. Plant Cell Environ. 2017, 40, 2644-2662. [CrossRef]

58. Devoto, A.; Nieto-Rostro, M.; Xie, D.; Ellis, C.; Harmston, R.; Patrick, E.; Davis, J.; Sherratt, L.; Coleman, M.; Turner, J.G. COI1 links jasmonate signalling and fertility to the SCF ubiquitin-ligase complex in Arabidopsis. Plant J. 2002, 32, 457-466. [CrossRef]

59. Dokládal, L.; Benková, E.; Honys, D.; Dupl'áková, N.; Lee, L.-Y.; Gelvin, S.B.; Sýkorová, E. An armadillo-domain protein participates in a telomerase interaction network. Plant Mol. Biol. 2018, 97, 407-420. [CrossRef] [PubMed]

60. Dong, C.-H.; Jang, M.; Scharein, B.; Malach, A.; Rivarola, M.; Liesch, J.; Groth, G.; Hwang, I.; Chang, C. Molecular association of the Arabidopsis ETR1 ethylene receptor and a regulator of ethylene signaling, RTE1. J. Biol. Chem. 2010, 285, 40706-40713. [CrossRef] [PubMed]

61. Feys, B.J.; Moisan, L.J.; Newman, M.A.; Parker, J.E. Direct interaction between the Arabidopsis disease resistance signaling proteins, EDS1 and PAD4. EMBO J. 2001, 20, 5400-5411. [CrossRef] [PubMed]

62. Forzani, C.; Carreri, A.; de van Fuente Bentem, S.; Lecourieux, D.; Lecourieux, F.; Hirt, H. The Arabidopsis protein kinase Pto-interacting 1-4 is a common target of the oxidative signal-inducible 1 and mitogen-activated protein kinases. FEBS J. 2011, 278, 1126-1136. [CrossRef] [PubMed]

63. Gao, W.; Li, H.-Y.; Xiao, S.; Chye, M.-L. Acyl-CoA-binding protein 2 binds lysophospholipase 2 and lysoPC to promote tolerance to cadmium-induced oxidative stress in transgenic Arabidopsis. Plant J. 2010, 62, 989-1003. [CrossRef] [PubMed]

64. Gibalová, A.; Steinbachová, L.; Hafidh, S.; Bláhová, V.; Gadiou, Z.; Michailidis, C.; Múller, K.; Pleskot, R.; Dupláková, N.; Honys, D. Characterization of pollen-expressed bZIP protein interactions and the role of ATbZIP18 in the male gametophyte. Plant Reprod. 2017, 30, 1-17. [CrossRef] [PubMed]

65. González, M.; Delgado-Requerey, V.; Ferrández, J.; Serna, A.; Cejudo, F.J. Insights into the function of NADPH thioredoxin reductase C (NTRC) based on identification of NTRC-interacting proteins in vivo. J. Exp. Bot. 2019, 70, 5787-5798. [CrossRef] [PubMed]

66. Gookin, T.E.; Assmann, S.M. Significant reduction of BiFC non-specific assembly facilitates in planta assessment of heterotrimeric G-protein interactors. Plant J. 2014, 80, 553-567. [CrossRef] [PubMed]

67. Guo, J.; Hu, Y.; Zhou, Y.; Zhu, Z.; Sun, Y.; Li, J.; Wu, R.; Miao, Y.; Sun, X. Profiling of the Receptor for Activated C Kinase 1a (RACK1a) interaction network in Arabidopsis thaliana. Biochem. Biophys. Res. Commun. 2019, 520, 366-372. [CrossRef]

68. Gupta, P.; Roy, S.; Nandi, A.K. MEDEA-interacting protein LONG-CHAIN BASE KINASE 1 promotes pattern-triggered immunity in Arabidopsis thaliana. Plant Mol. Biol. 2020, 103, 173-184. [CrossRef]

69. Henne, M.; König, N.; Triulzi, T.; Baroni, S.; Forlani, F.; Scheibe, R.; Papenbrock, J. Sulfurtransferase and thioredoxin specifically interact as demonstrated by bimolecular fluorescence complementation analysis and biochemical tests. FEBS Open Bio. 2015, 5, 832-843. [CrossRef]

70. Henrichs, S.; Wang, B.; Fukao, Y.; Zhu, J.; Charrier, L.; Bailly, A.; Oehring, S.C.; Linnert, M.; Weiwad, M.; Endler, A.; et al Regulation of ABCB1/PGP1-catalysed auxin transport by linker phosphorylation. EMBO J. 2012, 31, 2965-2980. [CrossRef]

71. Hernández-Sánchez, I.E.; Maruri-López, I.; Graether, S.P.; Jiménez-Bremont, J.F. In vivo evidence for homo- and heterodimeric interactions of Arabidopsis thaliana dehydrins AtCOR47, AtERD10, and AtRAB18. Sci. Rep. 2017, 7, 17036. [CrossRef] [PubMed]

72. Hino, T.; Tanaka, Y.; Kawamukai, M.; Nishimura, K.; Mano, S.; Nakagawa, T. Two Sec13p homologs, AtSec13A and AtSec13B, redundantly contribute to the formation of COPII transport vesicles in Arabidopsis thaliana. Biosci. Biotechnol. Biochem. 2011, 75, 1848-1852. [CrossRef] [PubMed]

73. Hou, P.; Ren, P.; Zeng, D.; Yu, G.; Tang, W.; Zheng, X.; Yang, J.; Liu, Y. Differential expression patterns and a novel interaction factor of Damaged DNA Binding Protein 1A (DDB1A) and DDB1B in Arabidopsis thaliana. J. Plant Biol. 2014, 57, 239-244. [CrossRef]

74. Huang, H.; Alvarez, S.; Nusinow, D.A. Data on the identification of protein interactors with the Evening Complex and PCH1 in Arabidopsis using tandem affinity purification and mass spectrometry (TAP-MS). Data Brief. 2016, 8, 56-60. [CrossRef] [PubMed]

75. Jeong, I.S.; Lee, S.; Bonkhofer, F.; Tolley, J.; Fukudome, A.; Nagashima, Y.; May, K.; Rips, S.; Lee, S.Y.; Gallois, P.; et al. Purification and characterization of Arabidopsis thaliana oligosaccharyltransferase complexes from the native host: A protein super-expression system for structural studies. Plant J. 2018, 94, 131-145. [CrossRef]

76. Jordá, L.; Sopeña-Torres, S.; Escudero, V.; Nuñez-Corcuera, B.; Delgado-Cerezo, M.; Torii, K.U.; Molina, A. ERECTA and BAK1 Receptor Like Kinases Interact to Regulate Immune Responses in Arabidopsis. Front. Plant Sci. 2016, 7, 897. [CrossRef] 
77. Junková, P.; Daněk, M.; Kocourková, D.; Brouzdová, J.; Kroumanová, K.; Zelazny, E.; Janda, M.; Hynek, R.; Martinec, J.; Valentová, O. Mapping of Plasma Membrane Proteins Interacting with Arabidopsis thaliana Flotillin 2. Front. Plant Sci. $2018,9,991$. [CrossRef]

78. Kaufholdt, D.; Baillie, C.-K.; Meyer, M.H.; Schwich, O.D.; Timmerer, U.L.; Tobias, L.; van Thiel, D.; Hänsch, R.; Mendel, R.R. Identification of a protein-protein interaction network downstream of molybdenum cofactor biosynthesis in Arabidopsis thaliana. J. Plant Physiol. 2016, 207, 42-50. [CrossRef]

79. Kauss, D.; Bischof, S.; Steiner, S.; Apel, K.; Meskauskiene, R. FLU, a negative feedback regulator of tetrapyrrole biosynthesis, is physically linked to the final steps of the $\mathrm{Mg}(++)$-branch of this pathway. FEBS Lett. 2012, 586, 211-216. [CrossRef]

80. Klostermann, E.; Droste Gen Helling, I.; Carde, J.-P.; Schünemann, D. The thylakoid membrane protein ALB3 associates with the cpSecY-translocase in Arabidopsis thaliana. Biochem. J. 2002, 368, 777-781. [CrossRef]

81. Kobayashi, Y.; Murata, M.; Minami, H.; Yamamoto, S.; Kagaya, Y.; Hobo, T.; Yamamoto, A.; Hattori, T. Abscisic acid-activated SNRK2 protein kinases function in the gene-regulation pathway of ABA signal transduction by phosphorylating ABA response element-binding factors. Plant J. 2005, 44, 939-949. [CrossRef] [PubMed]

82. Kumar, D.; Chattopadhyay, S. Glutathione modulates the expression of heat shock proteins via the transcription factors BZIP10 and MYB21 in Arabidopsis. J. Exp. Bot. 2018, 69, 3729-3743. [CrossRef]

83. Kuroda, H.; Yanagawa, Y.; Takahashi, N.; Horii, Y.; Matsui, M. A comprehensive analysis of interaction and localization of Arabidopsis SKP1-like (ASK) and F-box (FBX) proteins. PLoS ONE 2012, 7, e50009. [CrossRef] [PubMed]

84. Le, M.H.; Cao, Y.; Zhang, X.-C.; Stacey, G. LIK1, a CERK1-interacting kinase, regulates plant immune responses in Arabidopsis. PLoS ONE 2014, 9, e102245. [CrossRef]

85. Lee, H.-J.; Mochizuki, N.; Masuda, T.; Buckhout, T.J. Disrupting the bimolecular binding of the haem-binding protein 5 (AtHBP5) to haem oxygenase 1 (HY1) leads to oxidative stress in Arabidopsis. J. Exp. Bot. 2012, 63, 5967-5978. [CrossRef] [PubMed]

86. Li, H.-Y.; Xiao, S.; Chye, M.-L. Ethylene- and pathogen-inducible Arabidopsis acyl-CoA-binding protein 4 interacts with an ethylene-responsive element binding protein. J. Exp. Bot. 2008, 59, 3997-4006. [CrossRef] [PubMed]

87. Li, M.; Doll, J.; Weckermann, K.; Oecking, C.; Berendzen, K.W.; Schöffl, F. Detection of in vivo interactions between Arabidopsis class A-HSFs, using a novel BiFC fragment, and identification of novel class B-HSF interacting proteins. Eur. J. Cell Biol. 2010, 89, 126-132. [CrossRef]

88. Li, Z.; Li, Z.; Gao, X.; Chinnusamy, V.; Bressan, R.; Wang, Z.-X.; Zhu, J.-K.; Wu, J.-W.; Liu, D. ROP11 GTPase negatively regulates ABA signaling by protecting ABI1 phosphatase activity from inhibition by the ABA receptor RCAR1/PYL9 in Arabidopsis. J. Integr. Plant Biol. 2012, 54, 180-188. [CrossRef]

89. Li, Y.; Singhal, R.; Taylor, I.W.; McMinn, P.H.; Chua, X.Y.; Cline, K.; Fernandez, D.E. The Sec2 translocase of the chloroplast inner envelope contains a unique and dedicated SECE2 component. Plant J. 2015, 84, 647-658. [CrossRef]

90. Li, Y.; Im Kim, J.; Pysh, L.; Chapple, C. Four isoforms of Arabidopsis thaliana 4-coumarate: CoA ligase (4CL) have overlapping yet distinct roles in phenylpropanoid metabolism. Plant Physiol. 2015. [CrossRef]

91. Li, X.; Yang, R.; Gong, Y.; Chen, H. The Arabidopsis Mediator Complex Subunit MED19a is Involved in ABI5-mediated ABA Responses. J. Plant Biol. 2018, 61, 97-110. [CrossRef]

92. Li, S.; Zachgo, S. TCP3 interacts with R2R3-MYB proteins, promotes flavonoid biosynthesis and negatively regulates the auxin response in Arabidopsis thaliana. Plant J. 2013, 76, 901-913. [CrossRef] [PubMed]

93. Lomin, S.N.; Myakushina, Y.A.; Arkhipov, D.V.; Leonova, O.G.; Popenko, V.I.; Schmülling, T.; Romanov, G.A. Studies of cytokinin receptor-phosphotransmitter interaction provide evidences for the initiation of cytokinin signalling in the endoplasmic reticulum Funct. Plant Biol. 2018, 45, 192-202. [CrossRef]

94. Majerská, J.; Schrumpfová, P.P.; Dokládal, L.; Schořová, Š.; Stejskal, K.; Obořil, M.; Honys, D.; Kozáková, L.; Polanská, P.S.; Sýkorová, E. Tandem affinity purification of AtTERT reveals putative interaction partners of plant telomerase in vivo. Protoplasma 2017, 254, 1547-1562. [CrossRef] [PubMed]

95. Marais, C.; Wattelet-Boyer, V.; Bouyssou, G.; Hocquellet, A.; Dupuy, J.-W.; Batailler, B.; Brocard, L.; Boutté, Y.; Maneta-Peyret, L.; Moreau, P. The Qb-SNARE Memb11 interacts specifically with Arf1 in the Golgi apparatus of Arabidopsis thaliana. J. Exp. Bot. 2015, 66, 6665-6678. [CrossRef] [PubMed]

96. Marrocco, K.; Zhou, Y.; Bury, E.; Dieterle, M.; Funk, M.; Genschik, P.; Krenz, M.; Stolpe, T.; Kretsch, T. Functional analysis of EID1, an F-box protein involved in phytochrome A-dependent light signal transduction. Plant J. 2006, 45, 423-438. [CrossRef]

97. Maruri-López, I.; Jiménez-Bremont, J.F. Hetero- and homodimerization of Arabidopsis thaliana arginine decarboxylase AtADC1 and AtADC2. Biochem. Biophys. Res. Commun. 2017, 484, 508-513. [CrossRef]

98. McAndrew, R.S.; Olson, B.J.S.C.; Kadirjan-Kalbach, D.K.; Chi-Ham, C.L.; Vitha, S.; Froehlich, J.E.; Osteryoung, K.W. In vivo quantitative relationship between plastid division proteins FtsZ1 and FtsZ2 and identification of ARC6 and ARC3 in a native FtsZ complex. Biochem. J. 2008, 412, 367-378. [CrossRef]

99. Meng, L.-S.; Xu, M.-K.; Wan, W.; Yu, F.; Li, C.; Wang, J.-Y.; Wei, Z.-Q.; Lv, M.-J.; Cao, X.-Y.; Li, Z.-Y.; et al. Sucrose Signaling Regulates Anthocyanin Biosynthesis Through a MAPK Cascade in Arabidopsis thaliana. Genetics 2018, 210, 607-619. [CrossRef]

100. Miao, Y.; Smykowski, A.; Zentgraf, U. A novel upstream regulator of WRKY53 transcription during leaf senescence in Arabidopsis thaliana. Plant Biol. 2008, 10 (Suppl. S1), 110-120. [CrossRef] 
101. Mucha, S.; Heinzlmeir, S.; Kriechbaumer, V.; Strickland, B.; Kirchhelle, C.; Choudhary, M.; Kowalski, N.; Eichmann, R.; Hückelhoven, R.; Grill, E.; et al. The Formation of a Camalexin Biosynthetic Metabolon. Plant Cell 2019, 31, 2697-2710. [CrossRef] [PubMed]

102. Muthuramalingam, M.; Wang, Y.; Li, Y.; Mahalingam, R. Interacting protein partners of Arabidopsis RNA-binding protein AtRBP45b. Plant Biol. 2017, 19, 327-334. [CrossRef] [PubMed]

103. Nakazawa, Y.; Hiraguri, A.; Moriyama, H.; Fukuhara, T. The dsRNA-binding protein DRB4 interacts with the Dicer-like protein DCL4 in vivo and functions in the trans-acting siRNA pathway. Plant Mol. Biol. 2007, 63, 777-785. [CrossRef] [PubMed]

104. Nie, W.-F.; Wang, J. Actin-Related Protein 4 Interacts with PIE1 and Regulates Gene Expression in Arabidopsis. Genes 2021, 12, 520. [CrossRef] [PubMed]

105. Nintemann, S.J.; Vik, D.; Svozil, J.; Bak, M.; Baerenfaller, K.; Burow, M.; Halkier, B.A. Unravelling Protein-Protein Interaction Networks Linked to Aliphatic and Indole Glucosinolate Biosynthetic Pathways in Arabidopsis. Front. Plant Sci. 2017, 8, 2028. [CrossRef]

106. Nishimura, K.; Ishikawa, S.; Matsunami, E.; Yamauchi, J.; Homma, K.; Faulkner, C.; Oparka, K.; Jisaka, M.; Nagaya, T.; Yokota, K.; et al. New Gateway-compatible vectors for a high-throughput protein-protein interaction analysis by a bimolecular fluorescence complementation (BiFC) assay in plants and their application to a plant clathrin structure analysis. Biosci. Biotechnol. Biochem. 2015, 79, 1995-2006. [CrossRef]

107. Nishimura, K.; Matsunami, E.; Yoshida, S.; Kohata, S.; Yamauchi, J.; Jisaka, M.; Nagaya, T.; Yokota, K.; Nakagawa, T. The tyrosine-sorting motif of the vacuolar sorting receptor VSR4 from Arabidopsis thaliana, which is involved in the interaction between VSR4 and AP1M2, $\mu 1$-adaptin type 2 of clathrin adaptor complex 1 subunits, participates in the post-Golgi sorting of VSR4. Biosci. Biotechnol. Biochem. 2016, 80, 694-705. [CrossRef]

108. Noh, M.; Shin, J.S.; Hong, J.C.; Kim, S.Y.; Shin, J.S. Arabidopsis TCX8 functions as a senescence modulator by regulating LOX2 expression. Plant Cell Rep. 2021, 40, 677-689. [CrossRef]

109. O'Brien, M.; Kaplan-Levy, R.N.; Quon, T.; Sappl, P.G.; Smyth, D.R. PETAL LOSS, a trihelix transcription factor that represses growth in Arabidopsis thaliana, binds the energy-sensing SnRK1 kinase AKIN10. J. Exp. Bot. 2015, 66, 2475-2485. [CrossRef]

110. Occhialini, A.; Gouzerh, G.; Di Sansebastiano, G.-P.; Neuhaus, J.-M. Dimerization of the Vacuolar Receptors AtRMR1 and -2 from Arabidopsis thaliana contributes to their localization in the trans-Golgi Network. Int. J. Mol. Sci. 2016, 17, 1661. [CrossRef]

111. Park, J.; Lim, C.J.; Khan, I.U.; Jan, M.; Khan, H.A.; Park, H.J.; Guo, Y.; Yun, D.-J. Identification and Molecular Characterization of HOS15-interacting Proteins in Arabidopsis thaliana. J. Plant Biol. 2018, 61, 336-345. [CrossRef]

112. Pauwels, L.; Ritter, A.; Goossens, J.; Durand, A.N.; Liu, H.; Gu, Y.; Geerinck, J.; Boter, M.; Vanden Bossche, R.; de Clercq, R.; et al. The RING E3 Ligase KEEP ON GOING Modulates JASMONATE ZIM-DOMAIN12 Stability. Plant Physiol. 2015, 169, $1405-1417$. [CrossRef] [PubMed]

113. Perrella, G.; Davidson, M.L.H.; O’Donnell, L.; Nastase, A.-M.; Herzyk, P.; Breton, G.; Pruneda-Paz, J.L.; Kay, S.A.; Chory, J.; Kaiserli, E. ZINC-FINGER interactions mediate transcriptional regulation of hypocotyl growth in Arabidopsis. Proc. Natl. Acad. Sci. USA 2018, 115, E4503-E4511. [CrossRef] [PubMed]

114. Pitzschke, A.; Datta, S.; Persak, H. Salt stress in Arabidopsis: Lipid transfer protein AZI1 and its control by mitogen-activated protein kinase MPK3. Mol. Plant 2014, 7, 722-738. [CrossRef]

115. Pye, V.E.; Christensen, C.E.; Dyer, J.H.; Arent, S.; Henriksen, A. Peroxisomal plant 3-ketoacyl-CoA thiolase structure and activity are regulated by a sensitive redox switch. J. Biol. Chem. 2010, 285, 24078-24088. [CrossRef] [PubMed]

116. Rey, P.; Cuiné, S.; Eymery, F.; Garin, J.; Court, M.; Jacquot, J.-P.; Rouhier, N.; Broin, M. Analysis of the proteins targeted by CDSP32, a plastidic thioredoxin participating in oxidative stress responses. Plant J. 2005, 41, 31-42. [CrossRef]

117. Rodrigues, R.B.; Sabat, G.; Minkoff, B.B.; Burch, H.L.; Nguyen, T.T.; Sussman, M.R. Expression of a translationally fused TAP-tagged plasma membrane proton pump in Arabidopsis thaliana. J. Biochem. 2014, 53, 566-578. [CrossRef] [PubMed]

118. Roland, M.; Przybyla-Toscano, J.; Vignols, F.; Berger, N.; Azam, T.; Christ, L.; Santoni, V.; Wu, H.-C.; Dhalleine, T.; Johnson, M.K.; et al. The plastidial Arabidopsis thaliana NFU1 protein binds and delivers $4 \mathrm{Fe}-4 \mathrm{~S}$ clusters to specific client proteins. J. Biol. Chem. 2020, 295, 1727-1742. [CrossRef]

119. Roos, J.; Bejai, S.; Oide, S.; Dixelius, C. RabGAP22 is required for defense to the vascular pathogen Verticillium longisporum and contributes to stomata immunity. PLoS ONE 2014, 9, e88187. [CrossRef]

120. Santiago, J.; Rodrigues, A.; Saez, A.; Rubio, S.; Antoni, R.; Dupeux, F.; Park, S.-Y.; Márquez, J.A.; Cutler, S.R.; Rodriguez, P.L. Modulation of drought resistance by the abscisic acid receptor PYL5 through inhibition of clade A PP2Cs. Plant J. 2009, 60, 575-588. [CrossRef]

121. Sato, T.; Maekawa, S.; Yasuda, S.; Domeki, Y.; Sueyoshi, K.; Fujiwara, M.; Fukao, Y.; Goto, D.B.; Yamaguchi, J. Identification of 14-3-3 proteins as a target of ATL31 ubiquitin ligase, a regulator of the C/N response in Arabidopsis. Plant J. 2011, 68, 137-146. [CrossRef] [PubMed]

122. Struk, S.; Braem, L.; Walton, A.; de Keyser, A.; Boyer, F.-D.; Persiau, G.; de Jaeger, G.; Gevaert, K.; Goormachtig, S. Quantitative Tandem Affinity Purification, an Effective Tool to Investigate Protein Complex Composition in Plant Hormone Signaling: Strigolactones in the Spotlight. Front. Plant Sci. 2018, 9, 528. [CrossRef] [PubMed]

123. Tang, W.; Yuan, M.; Wang, R.; Yang, Y.; Wang, C.; Oses-Prieto, J.A.; Kim, T.-W.; Zhou, H.-W.; Deng, Z.; Gampala, S.S.; et al. PP2A activates brassinosteroid-responsive gene expression and plant growth by dephosphorylating BZR1. Nat. Cell Biol. 2011, 13, 124-131. [CrossRef] [PubMed] 
124. Tang, H.; Bi, H.; Liu, B.; Lou, S.; Song, Y.; Tong, S.; Chen, N.; Jiang, Y.; Liu, J.; Liu, H. WRKY33 interacts with WRKY12 protein to up-regulate RAP2.2 during submergence induced hypoxia response in Arabidopsis thaliana. New Phytol. 2021, 229, 106-125. [CrossRef] [PubMed]

125. Tarnowski, L.; Collados Rodriguez, M.; Brzywczy, J.; Cysewski, D.; Wawrzynska, A.; Sirko, A. Overexpression of the Selective Autophagy Cargo Receptor NBR1 Modifies Plant Response to Sulfur Deficit. Cells 2020, 9, 669. [CrossRef]

126. Templeton, G.W.; Nimick, M.; Morrice, N.; Campbell, D.; Goudreault, M.; Gingras, A.-C.; Takemiya, A.; Shimazaki, K.-I.; Moorhead, G.B.G. Identification and characterization of AtI-2, an Arabidopsis homologue of an ancient protein phosphatase 1 (PP1) regulatory subunit. Biochem. J. 2011, 435, 73-83. [CrossRef]

127. Tsugama, D.; Liu, S.; Takano, T. A bZIP protein, VIP1, interacts with Arabidopsis heterotrimeric G protein $\beta$ subunit, AGB1. Plant Physiol. Biochem. 2013, 71, 240-246. [CrossRef]

128. Valsecchi, I.; Guittard-Crilat, E.; Maldiney, R.; Habricot, Y.; Lignon, S.; Lebrun, R.; Miginiac, E.; Ruelland, E.; Jeannette, E.; Lebreton, S. The intrinsically disordered C-terminal region of Arabidopsis thaliana TCP8 transcription factor acts both as a transactivation and self-assembly domain. Mol. Biosyst. 2013, 9, 2282-2295. [CrossRef]

129. Van Hove, J.; de Jaeger, G.; Winne, N.; de Guisez, Y.; van Damme, E.J.M. The Arabidopsis lectin EULS3 is involved in stomatal closure. Plant Sci. 2015, 238, 312-322. [CrossRef]

130. Van Leene, J.; Blomme, J.; Kulkarni, S.R.; Cannoot, B.; de Winne, N.; Eeckhout, D.; Persiau, G.; van de Slijke, E.; Vercruysse, L.; Vanden Bossche, R.; et al. Functional characterization of the Arabidopsis transcription factor bZIP29 reveals its role in leaf and root development. J. Exp. Bot. 2016, 67, 5825-5840. [CrossRef]

131. Wang, C.; Chen, Q.; Xiang, N.; Liu, Y.; Kong, X.; Yang, Y.; Hu, X. SIP1, a novel SOS2 interaction protein, is involved in salt-stress tolerance in Arabidopsis. Plant Physiol. Biochem. 2018, 124, 167-174. [CrossRef] [PubMed]

132. Weis, C.; Pfeilmeier, S.; Glawischnig, E.; Isono, E.; Pachl, F.; Hahne, H.; Kuster, B.; Eichmann, R.; Hückelhoven, R. Co-immunoprecipitation-based identification of putative BAX INHIBITOR-1-interacting proteins involved in cell death regulation and plant-powdery mildew interactions. Mol. Plant Pathol. 2013, 14, 791-802. [CrossRef]

133. Wu, J.; Tan, X.; Wu, C.; Cao, K.; Li, Y.; Bao, Y. Regulation of cytokinesis by exocyst subunit SEC6 and KEULE in Arabidopsis thaliana Mol. Plant 2013, 6, 1863-1876. [CrossRef] [PubMed]

134. Xu, F.; Kapos, P.; Cheng, Y.T.; Li, M.; Zhang, Y.; Li, X. NLR-associating transcription factor bHLH84 and its paralogs function redundantly in plant immunity. PLoS Pathog. 2014, 10, e1004312. [CrossRef] [PubMed]

135. Yamaguchi, K.; Mezaki, H.; Fujiwara, M.; Hara, Y.; Kawasaki, T. Arabidopsis ubiquitin ligase PUB12 interacts with and negatively regulates Chitin Elicitor Receptor Kinase 1 (CERK1). PLoS ONE 2017, 12, e0188886. [CrossRef] [PubMed]

136. Yan, B.; Wang, X.; Wang, Z.; Chen, N.; Mu, C.; Mao, K.; Han, L.; Zhang, W.; Liu, H. Identification of potential cargo proteins of transportin protein AtTRN1 in Arabidopsis thaliana. Plant Cell Rep. 2016, 35, 629-640. [CrossRef] [PubMed]

137. Yasuda, S.; Sato, T.; Maekawa, S.; Aoyama, S.; Fukao, Y.; Yamaguchi, J. Phosphorylation of Arabidopsis ubiquitin ligase ATL31 is critical for plant carbon/nitrogen nutrient balance response and controls the stability of 14-3-3 proteins. J. Biol. Chem. 2014, 289, 15179-15193. [CrossRef] [PubMed]

138. Yazaki, J.; Galli, M.; Kim, A.Y.; Nito, K.; Aleman, F.; Chang, K.N.; Carvunis, A.-R.; Quan, R.; Nguyen, H.; Song, L.; et al. Mapping transcription factor interactome networks using HaloTag protein arrays. Proc. Natl. Acad. Sci. USA 2016, 113, E4238-47. [CrossRef]

139. Ye, Z.-W.; Chen, Q.-F.; Chye, M.-L. Arabidopsis thaliana Acyl-CoA-binding protein ACBP6 interacts with plasmodesmata-located protein PDLP8. Plant Signal. Behav. 2017, 12, e1359365. [CrossRef] [PubMed]

140. Yu, Y.; Chakravorty, D.; Assmann, S.M. The G Protein $\beta$-Subunit, AGB1, Interacts with FERONIA in RALF1-Regulated Stomatal Movement. Plant Physiol. 2018, 176, 2426-2440. [CrossRef] [PubMed]

141. Yue, K.; Sandal, P.; Williams, E.L.; Murphy, E.; Stes, E.; Nikonorova, N.; Ramakrishna, P.; Czyzewicz, N.; Montero-Morales, L.; Kumpf, R.; et al. PP2A-3 interacts with ACR4 and regulates formative cell division in the Arabidopsis root. Proc. Natl. Acad. Sci. USA 2016, 113, 1447-1452. [CrossRef] [PubMed]

142. Zhai, X.-T.; Wei, S.-S.; Liang, W.-Q.; Bai, J.-T.; Jia, N.; Li, B. Arabidopsis mtHSC70-1 physically interacts with the Cox2 subunit of cytochrome c oxidase. Plant Signal. Behav. 2020, 15, 1714189. [CrossRef] [PubMed]

143. Zhang, B.; Tremousaygue, D.; Denancé, N.; van Esse, H.P.; Hörger, A.C.; Dabos, P.; Goffner, D.; Thomma, B.P.H.J.; van der Hoorn, R.A.L.; Tuominen, H. PIRIN2 stabilizes cysteine protease XCP2 and increases susceptibility to the vascular pathogen Ralstonia solanacearum in Arabidopsis. Plant J. 2014, 79, 1009-1019. [CrossRef] [PubMed]

144. Zhang, Y.; Du, N.; Li, K.; Feng, J. msiDBN: A method of identifying critical proteins in dynamic PPI networks. Biomed. Res. Int. 2014, 2014, 138410. [CrossRef]

145. Zhang, L.; Zhang, X.; Ju, H.; Chen, J.; Wang, S.; Wang, H.; Zhao, Y.; Chang, Y. Ovate family protein1 interaction with BLH3 regulates transition timing from vegetative to reproductive phase in Arabidopsis. Biochem. Biophys. Res. Commun. 2016, 470, 492-497. [CrossRef] [PubMed]

146. Zhang, L.; Sun, L.; Zhang, X.; Zhang, S.; Xie, D.; Liang, C.; Huang, W.; Fan, L.; Fang, Y.; Chang, Y. OFP1 Interaction with ATH1 Regulates Stem Growth, Flowering Time and Flower Basal Boundary Formation in Arabidopsis. Genes 2018, 9, 399. [CrossRef]

147. Zhang, Y.; Swart, C.; Alseekh, S.; Scossa, F.; Jiang, L.; Obata, T.; Graf, A.; Fernie, A.R. The Extra-Pathway Interactome of the TCA Cycle: Expected and Unexpected Metabolic Interactions. Plant Physiol. 2018, 177, 966-979. [CrossRef]

148. Zhang, X.; Wu, S.; Liu, S.; Takano, T. The Arabidopsis sucrose non-fermenting-1-related protein kinase AtSnRK2.4 interacts with a transcription factor, AtMYB21, that is involved in salt tolerance. Plant Sci. 2021, 303, 110685. [CrossRef] [PubMed] 
149. Zhang, Y.; McCormick, S. A distinct mechanism regulating a pollen-specific guanine nucleotide exchange factor for the small GTPase Rop in Arabidopsis thaliana. Proc. Natl. Acad. Sci. USA 2007, 104, 18830-18835. [CrossRef]

150. Zhao, Q.; Brkljacic, J.; Meier, I. Two distinct interacting classes of nuclear envelope-associated coiled-coil proteins are required for the tissue-specific nuclear envelope targeting of Arabidopsis RanGAP. Plant Cell 2008, 20, 1639-1651. [CrossRef]

151. Zhao, H.; Xing, D.; Li, Q.Q. Unique features of plant cleavage and polyadenylation specificity factor revealed by proteomic studies. Plant Physiol. 2009, 151, 1546-1556. [CrossRef] [PubMed]

152. Zhu, H.; Li, G.-J.; Ding, L.; Cui, X.; Berg, H.; Assmann, S.M.; Xia, Y. Arabidopsis extra large G-protein 2 (XLG2) interacts with the Gbeta subunit of heterotrimeric $G$ protein and functions in disease resistance. Mol. Plant 2009, 2, 513-525. [CrossRef] [PubMed]

153. Zhu, L.; Chu, L.-C.; Liang, Y.; Zhang, X.-Q.; Chen, L.-Q.; Ye, D. The Arabidopsis CrRLK1L protein kinases BUPS1 and BUPS2 are required for normal growth of pollen tubes in the pistil. Plant J. 2018, 95, 474-486. [CrossRef] [PubMed]

154. Zhu, L.; Zhang, X.-Q.; Ye, D.; Chen, L.-Q. The Mildew Resistance Locus O 4 interacts with CaM/CML and is involved in root gravity response. Int. J. Mol. Sci. 2021, 22, 5962. [CrossRef]

155. Olejnik, K.; Bucholc, M.; Anielska-Mazur, A.; Lipko, A.; Kujawa, M.; Modzelan, M.; Augustyn, A.; Kraszewska, E. Arabidopsis thaliana Nudix hydrolase AtNUDT7 forms complexes with the regulatory RACK1A protein and Ggamma subunits of the signal transducing heterotrimeric G protein. Acta Biochim. Pol. 2011, 58, 609-616. [CrossRef] [PubMed]

156. Schneider, A.; Steinberger, I.; Strissel, H.; Kunz, H.-H.; Manavski, N.; Meurer, J.; Burkhard, G.; Jarzombski, S.; Schünemann, D.; Geimer, S.; et al. The Arabidopsis Tellurite resistance C protein together with ALB3 is involved in photosystem II protein synthesis. Plant J. 2014, 78, 344-356. [CrossRef]

157. Serivichyaswat, P.; Ryu, H.-S.; Kim, W.; Kim, S.; Chung, K.S.; Kim, J.J.; Ahn, J.H. Expression of the Floral Repressor miRNA156 is Positively Regulated by the AGAMOUS-like Proteins AGL15 and AGL18. Mol. Cells 2015, 38, 259-266. [CrossRef]

158. Sijacic, P.; Holder, D.H.; Bajic, M.; Deal, R.B. Methyl-CpG-binding domain 9 (MBD9) is required for H2A.Z incorporation into chromatin at a subset of H2A.Z-enriched regions in the Arabidopsis genome. PLoS Genet. 2019, 15, e1008326. [CrossRef]

159. Skrzypczak, T.; Krela, R.; Wadurkar, S.; Gevaert, K.; van de Slijke, E.; de Jaeger, G.; Leśniewicz, K.; Wojtaszek, P. Characterization of the $\gamma$-secretase subunit interactome in Arabidopsis thaliana. Acta Physiol. Plant 2019, 41. [CrossRef]

160. Stankovic, N.; Schloesser, M.; Joris, M.; Sauvage, E.; Hanikenne, M.; Motte, P. Dynamic Distribution and Interaction of the Arabidopsis SRSF1 Subfamily Splicing Factors. Plant Physiol. 2016, 170, 1000-1013. [CrossRef]

161. Stenzel, I.; Otto, M.; Delker, C.; Kirmse, N.; Schmidt, D.; Miersch, O.; Hause, B.; Wasternack, C. ALLENE OXIDE CYCLASE (AOC) gene family members of Arabidopsis thaliana: Tissue- and organ-specific promoter activities and in vivo heteromerization. J. Exp. Bot. 2012, 63, 6125-6138. [CrossRef] [PubMed]

162. Szklarczyk, D.; Gable, A.L.; Nastou, K.C.; Lyon, D.; Kirsch, R.; Pyysalo, S.; Doncheva, N.T.; Legeay, M.; Fang, T.; Bork, P.; et al. The STRING database in 2021: Customizable protein-protein networks, and functional characterization of user-uploaded gene/measurement sets. Nucleic Acid Res. 2021, 49, D605-D612. [CrossRef] [PubMed]

163. Cosse, M.; Seidel, T. Plant Proton Pumps and Cytosolic pH-Homeostasis. Front. Plant Sci. 2021, 12, 672873. [CrossRef] [PubMed]

164. Klychnikov, O.I.; Li, K.W.; Lill, H.; de Boer, A.H. The V-ATPase from etiolated barley (Hordeum vulgare L.) shoots is activated by blue light and interacts with 14-3-3 proteins. J. Exp. Bot. 2007, 58, 1013-1023. [CrossRef]

165. Trigg, S.A.; Garza, R.M.; MacWilliams, A.; Nery, J.R.; Bartlett, A.; Castanon, R.; Goubil, A.; Feeney, J.; O’Malley, R.; Huang, S.-S.C.; et al. CrY2H-seq: A massively multiplexed assay for deep-coverage interactome mapping. Nat. Meth. 2017, 14, 819-825. [CrossRef]

166. Jones, A.M.; Xuan, Y.; Xu, M.; Wang, R.-S.; Ho, C.-H.; Lalonde, S.; You, C.H.; Sardi, M.I.; Parsa, S.A.; Smith-Valle, E.; et al. Border control-a membrane-linked interactome of Arabidopsis. Science 2014, 344, 711-716. [CrossRef]

167. McWhite, C.D.; Papoulas, O.; Drew, K.; Dang, V.; Leggere, J.C.; Sae-Lee, W.; Marcotte, E.M. Co-fractionation/mass spectrometry to identify protein complexes. STAR Protoc. 2021, 2, 100370. [CrossRef]

168. McWhite, C.D.; Papoulas, O.; Drew, K.; Cox, R.M.; June, V.; Dong, O.X.; Kwon, T.; Wan, C.; Salmi, M.L.; Roux, S.J.; et al. A Pan-plant Protein Complex Map Reveals Deep Conservation and Novel Assemblies. Cell 2020, 181, 460-474. [CrossRef]

169. Popescu, S.C.; Popescu, G.V.; Bachan, S.; Zhang, Z.; Seay, M.; Gerstein, M.; Snyder, M.; Dinesh-Kumar, S.P. Differential binding of calmodulin-related proteins to their targets revealed through high-density Arabidopsis protein microarrays. Proc. Natl. Acad. Sci. USA 2007, 104, 4730-4735. [CrossRef]

170. Dreze, M.; Carvunis, A.-R.; Charloteaux, B.; Galli, M.; Pevzner, S.J.; Tasan, M.; Ahn, Y.-Y.; Balumuri, P.; Barabasi, A.-L.; Bautista, V.; et al. Evidence for Network Evolution in an Arabidopsis Interactome Map. Science 2011, 333, 601-607. [CrossRef]

171. Altmann, M.; Altmann, S.; Rodriguez, P.A.; Weller, B.; Elorduy Vergara, L.; Palme, J.; Marín-de la Rosa, N.; Sauer, M.; Wenig, M.; Villaécija-Aguilar, J.A.; et al. Extensive signal integration by the phytohormone protein network. Nature 2020, 583, 271-276. [CrossRef] [PubMed]

172. Mott, G.A.; Smakowska-Luzan, E.; Pasha, A.; Parys, K.; Howton, T.C.; Neuhold, J.; Lehner, A.; Grünwald, K.; Stolt-Bergner, P.; Provart, N.J.; et al. Map of physical interactions between extracellular domains of Arabidopsis leucine-rich repeat receptor kinases. Sci. Data 2019, 6, 190025. [CrossRef] [PubMed]

173. Kim, D.Y.; Scalf, M.; Smith, L.M.; Vierstra, R.D. Advanced proteomics analyses yield a deep catalog of ubiquitylation targets in Arabidopsis. Plant Cell 2013, 25, 1523-1540. [CrossRef] [PubMed] 
174. Smakowska-Luzan, E.; Mott, G.A.; Parys, K.; Stegmann, M.; Howton, T.C.; Layeghifard, M.; Neuhold, J.; Lehner, A.; Kong, J.; Grünwald, K.; et al. An extracellular network of Arabidopsis leucine-rich repeat receptor kinases. Nature 2018, 553, 342-346. [CrossRef] [PubMed]

175. Grefen, C.; Obrdlik, P.; Harter, K. The determination of protein-protein interactions by the mating-based split-ubiquitin system (mbSUS). Methods Mol. Biol. 2009, 479, 217-233. [CrossRef] [PubMed]

176. Hayek, S.R.; Rane, H.S.; Parra, K.J. Reciprocal regulation of V-ATPase and glycolytic pathway elements in health and disease. Front. Physiol. 2019, 10, 127. [CrossRef] [PubMed]

177. Schnitzer, D.; Seidel, T.; Sander, T.; Golldack, D.; Dietz, K.J. The cellular energization state affects peripheral stalk stability of plant vacuolar $\mathrm{H}^{+}$-ATPase and impairs vacuolar acidification. Plant Cell Physiol. 2011, 52, 946-956. [CrossRef] [PubMed]

178. Cho, Y.H.; Sang-Dong, Y.; Sheen, J. Regulatory funtions of nuclear hexokinase complex in glucose signaling. Cell 2006, 127, 579-589. [CrossRef] [PubMed]

179. Konishi, H.; Maeshima, M.; Komatsu, S. Characterization of vacuolar membrane proteins changed in rice root treated with gibberellin. J. Proteome Res. 2005, 4, 1775-1780. [CrossRef] [PubMed]

180. Brüx, A.; Liu, T.Y.; Krebs, M.; Stierhog, Y.D.; Lohmann, J.U.; Miersch, O.; Wasternack, C.; Schumacher, K. Reduced V-ATPase activity in the trans-Golgi network causes oxylipin-dependent hypocotyl growth inhibition in Arabidopsis. Plant Cell 2008, 20, 1088-1100. [CrossRef]

181. Seidel, T.; Golldack, D.; Dietz, K.J. Mapping of C-termini of V-ATPase subunits by in vivo FRET measurements. FEBS Lett. 2005, 579, 4374-4382. [CrossRef] [PubMed]

182. Viotti, C.; Krüger, F.; Krebs, M.; Neubert, C.; Fink, F.; Lupanga, U.; Scheuring, D.; Boutté, Y.; Frescatada-Rosa, M.; Wolfenstetter, S.; et al. The endoplasmic reticulum is the main membrane source for biogenesis of the lytic vacuole in Arabidopsis. Plant Cell 2013, 25, 3434-3449. [CrossRef] [PubMed]

183. Seidel, T.; Siek, M.; Marg, B.; Dietz, K.J. Energization of vacuolar transport in plant cells and its significance under stress. Int. Rev. Cell Mol. Biol. 2013, 304, 57-131. [CrossRef] [PubMed]

184. Siao, W.; Wang, P.; Voigt, B.; Hussey, P.J.; Baluska, F. Arabidopsis SYT1 maintains stability of cortical endoplasmic reticulum networks and VAP27-1-enriched endoplasmic reticulum-plasma membrane contact sites. J. Exp Bot. 2016, 67, 6161-6171. [CrossRef] [PubMed] 